\title{
Monitoring the Recent Activity of Landslides in the Mailuu-Suu Valley (Kyrgyzstan) Using Radar and Optical Remote Sensing Techniques
}

\author{
Valentine Piroton ${ }^{1, * \mathbb{C}}$, Romy Schlögel ${ }^{2} \mathbb{D}$, Christian Barbier ${ }^{3}$ and Hans-Balder Havenith ${ }^{1} \mathbb{C}$ \\ 1 Department of Geology, University of Liège, 4000 Liège, Belgium; hb.havenith@uliege.be \\ 2 Division for Satellite Analysis and Applied Research (UNOSAT), United Nations Institute for Training and \\ Research (UNITAR), United Nations Office at Nairobi, Nairobi 00200, Kenya; romy.schlogel@gmail.com \\ 3 Signal Processing Laboratory, Centre Spatial de Liège (CSL), Liège University, 4000 Liège, Belgium; \\ cbarbier@uliege.be \\ * Correspondence: v.piroton@uliege.be; Tel.: +32-4-366-20-65
}

Received: 30 March 2020; Accepted: 29 April 2020; Published: 1 May 2020

\begin{abstract}
Central Asian mountain regions are prone to multiple types of natural hazards, often causing damage due to the impact of mass movements. In spring 2017, Kyrgyzstan suffered significant losses from a massive landslide activation event, during which also two of the largest deep-seated mass movements of the former mining area of Mailuu-Suu - the Koytash and Tektonik landslides-were reactivated. This study consists of the use of optical and radar satellite data to highlight deformation zones and identify displacements prior to the collapse of Koytash and to the more superficial deformation on Tektonik. Especially for the first one, the comparison of Digital Elevation Models of 2011 and 2017 (respectively, satellite and unmanned aerial vehicle (UAV) imagery-based) highlights areas of depletion and accumulation, in the scarp and near the toe, respectively. The Differential Synthetic Aperture Radar Interferometry analysis identified slow displacements during the months preceding the reactivation in April 2017, indicating the long-term sliding activity of Koytash and Tektonik. This was confirmed by the computation of deformation time series, showing a positive velocity anomaly on the upper part of both landslides. Furthermore, the analysis of the Normalized Difference Vegetation Index revealed land cover changes associated with the sliding process between June 2016 and October 2017. In addition, in situ data from a local meteorological station highlighted the important contribution of precipitation as a trigger of the collapse. The multidirectional approach used in this study demonstrated the efficiency of applying multiple remote sensing techniques, combined with a meteorological analysis, to identify triggering factors and monitor the activity of landslides.
\end{abstract}

Keywords: landslide monitoring; Kyrgyzstan; Sentinel-1; D-InSAR; NDVI; DEMs; remote sensing; differential interferometry

\section{Introduction}

Between 2005 and 2014, non-event related landslides were responsible for 4506 deaths in the 40 most mountainous countries of the world, excluding tens of thousands of deaths linked to landslides triggered by earthquakes [1]. Such natural disasters can often lead to catastrophic consequences, especially in mountainous areas where intense rainfall, high regional seismicity, weak geological materials, and steep slopes act as major triggers or predisposition factors. Therefore, it is essential to monitor landslides and to analyze related mechanisms in order to reduce and prevent the negative socioeconomic impacts linked to these natural hazards. The improvement of spatial and temporal resolution of satellite imagery, along with the development of novel techniques, makes it currently possible to cover large 
geographic areas and collect huge amounts of data periodically [2]. These geodatabases can be used before the disaster to create susceptibility maps and monitor high risk zones, but also to identify low-risk rehabilitation zones post-landslide. In this context, remote sensing is a powerful tool for landslide disaster management, including risk evaluation and hazard assessment.

In Central Asia, landslide risks are enhanced by the intense tectonic activity, resulting from the ongoing collision between the Indian and the Eurasian plates [3,4] (Figure 1b). Kyrgyzstan, with 82\% of its territory representing mountainous land area [1], is highly prone to such natural hazards. Intense rainfall and rapid snowmelt during spring seasons, as well as the persistent seismic activity, further accentuates landslide risks in this country, particularly along the northern and eastern rim of the Fergana Basin (Figure 1). In the Kyrgyz part of the Fergana Basin, near the town of Maily-Say, the first recorded massive activation of landslides occurred in 1954 and was followed by other events in 1958, 1969, 1979, 1988, 1993-1994, 1998, and 2003-2005 [5,6]. These activations were most likely triggered by a combination of several meteorological factors (e.g., rainfall and snowfall). The most recent and most intense activation (among all recorded ones) occurred in spring 2017. In total, 160 large $\left(>100,000 \mathrm{~m}^{3}\right)$ and hundreds of small $\left(<100,000 \mathrm{~m}^{3}\right)$ landslides have been triggered or reactivated during this major event, displacing an estimated total volume of more than 82 million $\mathrm{m}^{3}$ [6]. A recent study has shown the evolution of the annual number of landslides in the region of Mailuu-Suu [7]. According to related results, the highest yearly rates (before 2017) of landslides were observed for the years 2010 and 2016. Within a study area of $12,000 \mathrm{~km}^{2}$ located at the eastern rim of the Fergana Basin, 230 landslides-former or new-are recorded per year, affecting an overall area of more than $2 \mathrm{~km}^{2}$ [7]. These results support those published by Havenith et al. [5], which already highlighted an increase in the total area impacted by landslides in that valley since 1962. As previously demonstrated by Havenith et al. [6], this recurrent activation of mass movements is mainly observed during the spring season, resulting from a combined action of geological and climatic factors [6]. Due to the significant societal, economic, and environmental impacts related to mass movements around the city of Maily-Say, understanding the mechanisms underlying the reactivation of landslides has become a key question to prevent massive losses due to landslides in that region.

Over the past decades, numerous remote sensing techniques have been developed and employed in this context. Differential Synthetic Aperture Radar (SAR) Interferometry (D-InSAR), which is widely used to monitor movements related to the activities of volcanoes, earthquakes, glacier retreats, and landslides, allows measurement of the displacements along the line-of-sight (LOS) of a satellite [8-13]. As this technique is based on the distance changes between the sensor and targets located at the Earth surface, slight ground displacements, such as slow landslides, can nowadays be measured over wide areas with an accuracy of around a centimeter [14-17].

While D-InSAR is suitable for the detection of slow vertical displacements, Digital Elevation Models (DEMs) and optical images can be used to identify fast horizontal movements. DEMs, which depict the topography of a land surface, are obtained from radar images or Unmanned Aerial Vehicle (UAV) acquisitions. Using pre- and post-failure DEMs, the accumulation and depletion zones of a landslide can be delimited [18]. Moreover, vegetation indexes, such as the Normalized Difference Vegetation Index (NDVI), are widely used to study landslides [19-24]. By comparing two images taken at different time periods, the difference in NDVI, pixel by pixel, highlights changes in vegetation cover linked to fast mass movements $[24,25]$. Thus, optical data are useful for change detection and for the identification of visible features in 2D (map view). Depending on the spatial resolution, optical satellite images are also commonly used for the geomorphic mapping of inaccessible mountainous areas. 

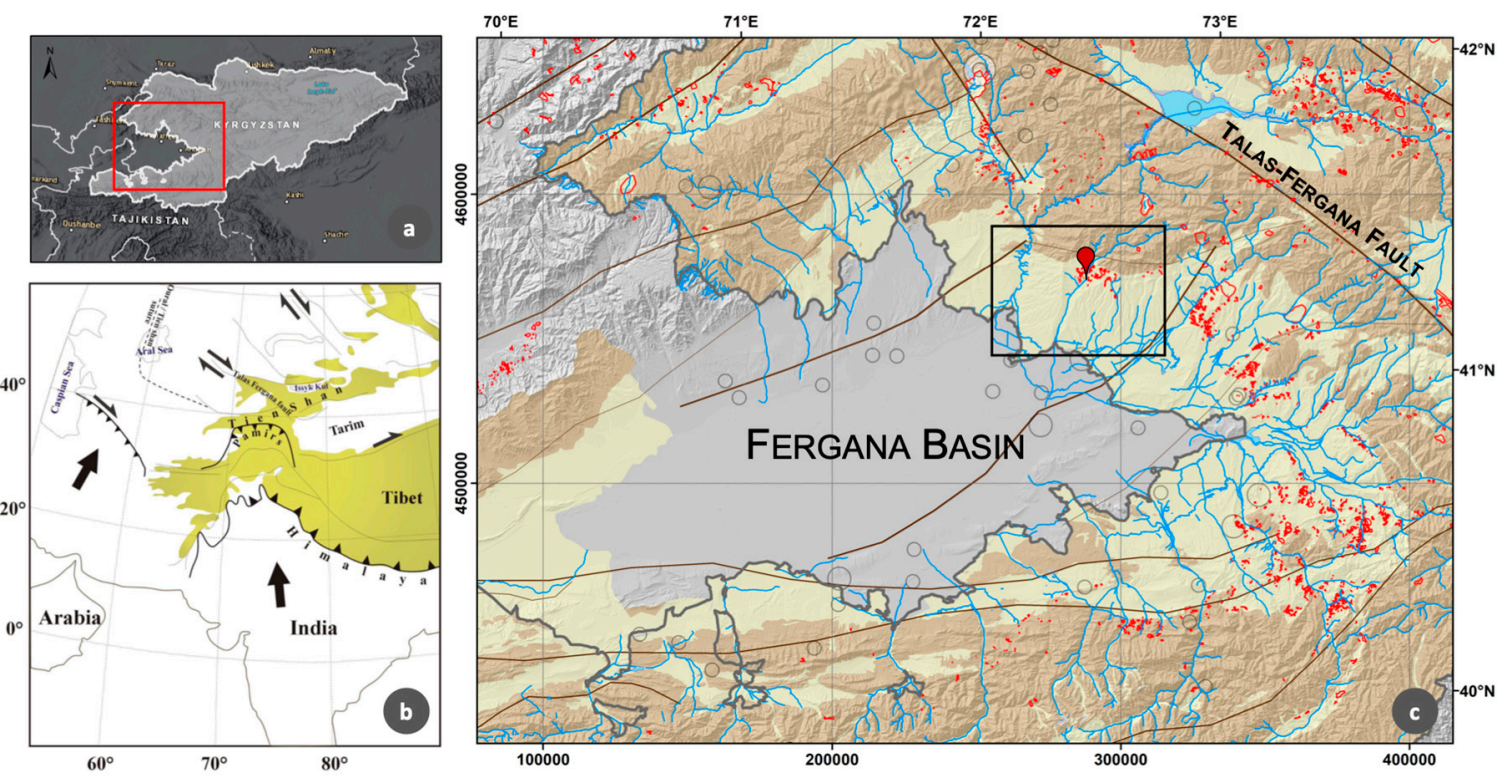

100000

Figure 1. (a) Location of Kyrgyzstan and the Fergana Basin (see the red square). (b) Tectonic map representing the collision between the Eurasian and Indian plates. The regions located at altitudes $<2000 \mathrm{~m}$ are colored in green [26]. (c) Fergana Basin and the Mailuu-Suu Valley (see the black square) on the simplified geological map of the Western Tien Shan. Zones colored in beige represent Cenozoic, Mesozoic soft rocks, and sediments, while zones in brown indicate Pre-Mesozoic and magmatic rocks. The circles show the location of major $(M \geq 5.5)$ earthquake epicenters and the red dots represent the landslides (see Havenith et al. [27]). The red pin shows the location of the town of Maily-Say, the black and blue lines indicate the faults and the waterbodies respectively.

In this study, we employ multiple distinct and complementary methods to understand the recent collapse of the Koytash landslide and the deformation affecting the neighboring Tektonik mass movement (see view shown in Figure 2). We detect terrain elevation changes related to both fast and slow displacements of the ground surface by using UAV-based imagery combined with radar and optical remote sensing techniques. In addition, we conducted a meteorological analysis to identify the triggering conditions, which led to slope instabilities.

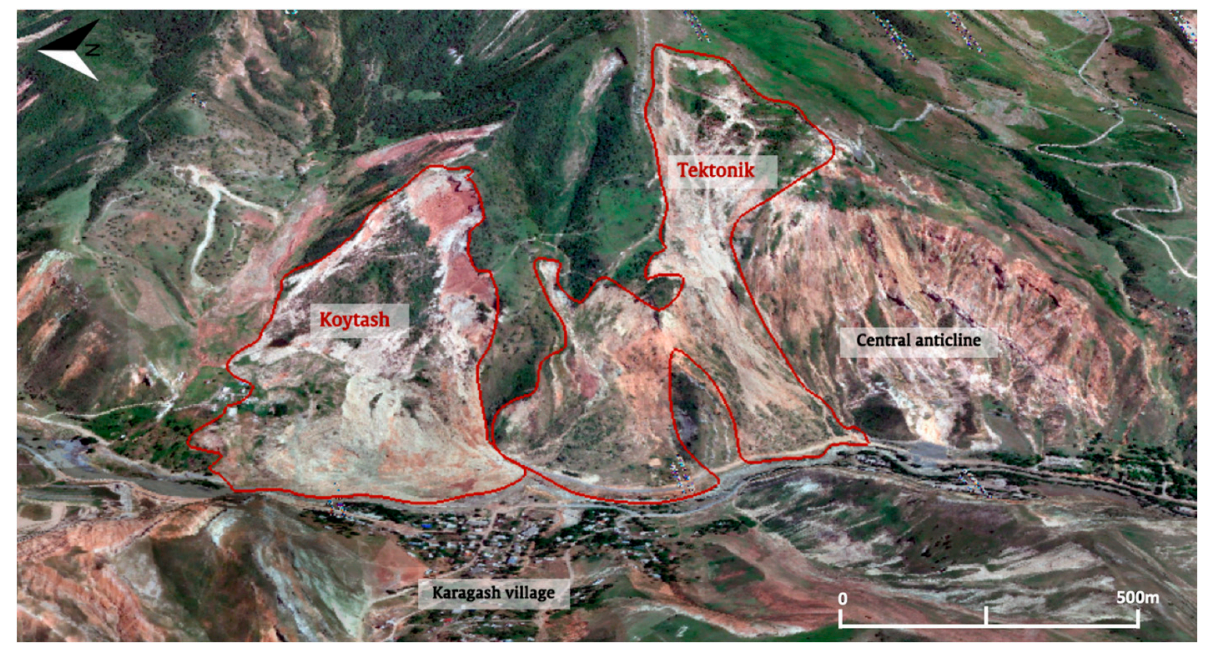

Figure 2. 3D view of the Koytash and Tektonik landslides, produced with ArcScene on the basis of images from the World Imagery (Digital Globe, Google Earth (C)). The village of Karagash, part of the larger town of Maily-Say, is located in the foreground, and the central anticline is on the right. 


\section{Study Area}

Kyrgyzstan is located in the middle of Central Asia and crossed by the geohazard-prone mountain range of the Tien Shan, with peaks reaching altitudes of $7000 \mathrm{~m}$. According to the Ministry of Emergency Situations of the Kyrgyz Republic, more than 7\% of the total territory, representing an area of approximately $15,000 \mathrm{~km}^{2}$, could potentially be affected by landslides. The most susceptible regions to slope failure are located along the northern and eastern rim of the Fergana Basin, which is also marked by the highest population density [6]. In this area, mass movements are concentrated in a range of altitudes between 700 and $2000 \mathrm{~m}$. These landslides, often characterized by deep and steep scarps, mobilize weakly consolidated sediments of Tertiary or Quaternary age, including loess deposits $[7,19,28]$. The Mailuu-Suu Valley is a former uranium mining area in the Jalal-Abad region, southern Kyrgyzstan at the north-eastern border of the Fergana Basin. This region is particularly prone to landslide hazards and, during the last 50 years, has experienced severe landslide disasters in the vicinity of numerous nuclear waste tailings. The high intensity of natural hazards in that area is due, on one hand, to its location between the mountain range and the basin marked by a relatively wet climate and, on the other hand, to the presence of soft geological materials near the surface [23] (see the geological map of Maily-Say in Figure A1). This type of sediment is prone to gravitational mass movements initiated by intense precipitations or strong seismic ground shaking [6,23,29-31]. Due to the presence of radioactive wastes produced by past mining activities, this region is exposed to a high risk of environmental contamination and demands particular attention (Figure 3). As a result, landslides represent a major threat to the local population of the small town of Maily-Say and of the regions downstream, not only through the direct impact, but also through indirect effects that lead to the creation of landslide dams that may block the river and cause the formation of a lake. Such lakes represent a further threat for downstream populations due to the potential failure of the landslide dam, causing the release of huge amounts of water resulting in floods. In the case of Maily-Say, the lake could also possibly reach the level of the nuclear waste tailings and thus cause their instability and the related mobilization of radioactive material. In 2003, Vandenhove et al. [30] identified 23 mine tailings and 13 nuclear landfills for a total volume of approximately 3 million $\mathrm{m}^{3}$ (see tailing locations in the geological map in Figure A1). Due to its critical situation, Mailuu-Suu Valley was and still is the target area of several international risk assessment projects [4].

During the 1990s, three of the largest landslides of the Mailuu-Suu Valley (i.e., Koytash, Tektonik, and Isolith; the first two are shown in Figure 2), displaced more than 5 million $\mathrm{m}^{3}$ of material [32]. These three landslides are located near the core of the central anticline and represent the greatest threat for the destabilization of some nuclear waste tailings [6,33]. According to Havenith et al. [6], the Mailuu-Suu landslides now extend over an area of approximately $10 \mathrm{~km}^{2}$. Havenith et al. [5] also showed that distant earthquakes (epicentral distance $>100 \mathrm{~km}$ ), even of a magnitude less than 6 , can induce slight displacements on landslide slopes in the Mailuu-Suu Valley.

The Koytash landslide (see location in Figure 3) has been extensively studied for many years as it has been active since the 50's $[5,23,29,34,35]$. Two elements indicate that this landslide is characterized by a roto-translational movement: First, the presence of a steeply dipping scarp at the crest of the landslide, showing slickensides, indicates sliding rather than a simple detachment as would be expected for a translational landslide. Second, the landslide body slides along a paleogenic limestone basement with a slope steeper than the ground surface. Although some translational sliding occurs above the limestone along the internal paleogenic clay layers, the base of the landslide is more than $50 \mathrm{~m}$ deep, which requires a rotational component. Furthermore, some anti-dip slope scarps in the lower part of the landslide also suggest some rotational movements. These observations are based on Electrical Resistivity Tomography (ERT) measurements completed by one of the authors (H.B. Havenith) together with the GEOPRIBOR team (led by I. Torgoev, Kyrgyzstan) [36]. Havenith et al. [5] evaluated its average annual speed at $60 \mathrm{~cm} /$ year and its volume at 5 million $\mathrm{m}^{3}$. In 2009, Schlögel [37] estimated the average speed of the movement at 1-2 mm/day and recognized Koytash as a major threat due to the possibility of a river dam. This roto-translational landslide was massively reactivated on the 
22nd of April 2017 blocking the Mailuu-Suu River. Due to the damming of the valley, a lake formed with a depth of $\sim 15 \mathrm{~m}$, almost reaching the base of the nearest tailing. A few weeks later, after the dredging of the dam to open a channel for the river, the dam partially failed and the lake progressively disappeared [38]. The rupture in spring 2017 also destroyed a few houses at the foothill of Koytash; these houses had already been evacuated due to the landslide risks [38].
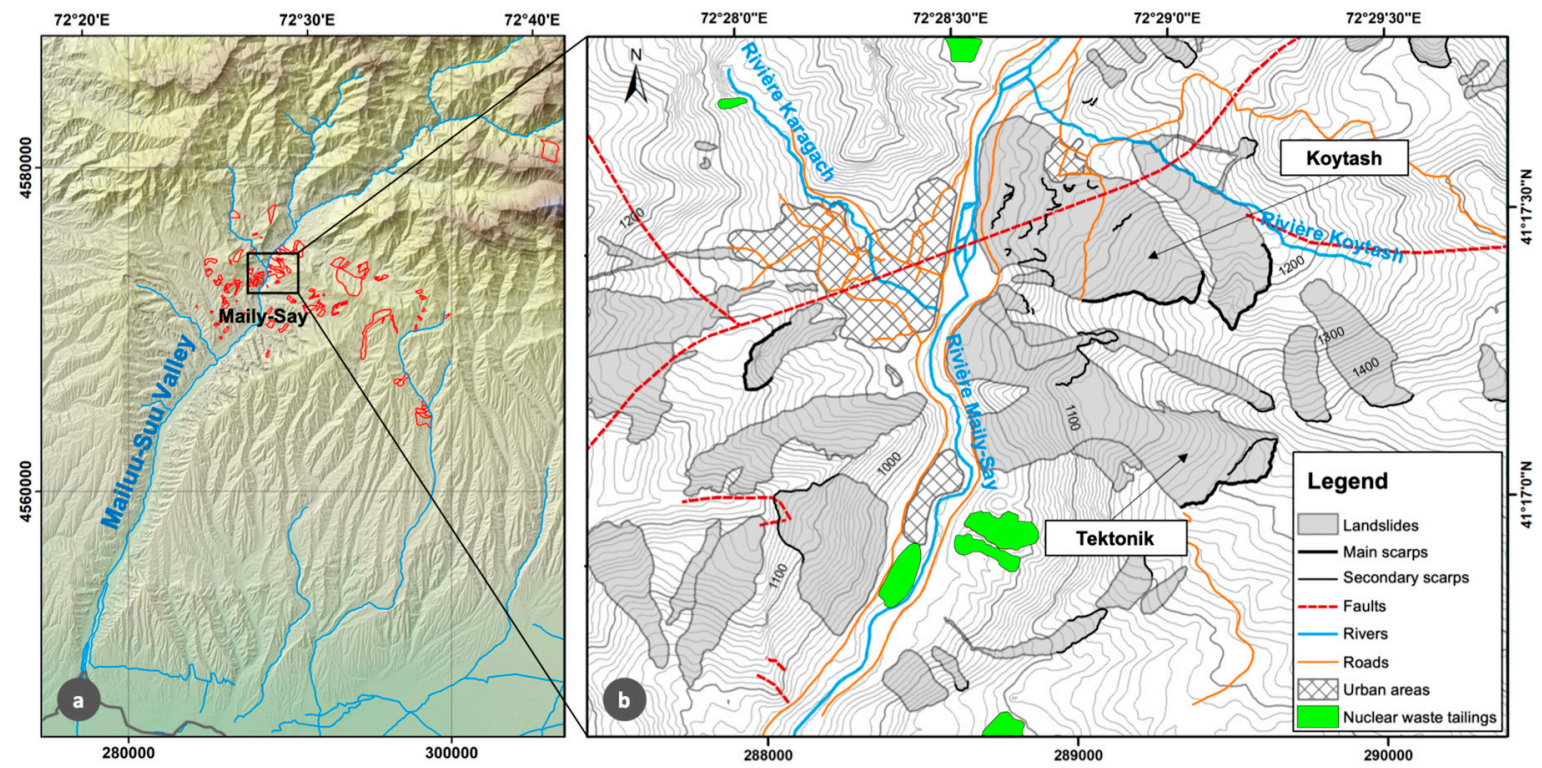

Figure 3. (a) Location of the target area within the Mailuu-Suu Valley on the TanDEM-X hillshade (spatial resolution: $12 \mathrm{~m}$ ). The blue lines represent the rivers and the landslides are outlined in red. (b) Geomorphological map of the landslides in the Mailuu-Suu Valley in Kyrgyzstan (gray polygons), main and secondary escarpments (black lines), faults (red dotted lines), rivers (blue lines), roads (orange lines), urban areas (grid polygons), and nuclear waste (red polygons). The elevation lines (gray lines) are built from a TanDEM-X Digital Elevation Model (DEM) (spatial resolution: $12 \mathrm{~m}$ ).

Second, in addition to Koytash, we studied the large Tektonik landslide (perspective view in Figure 2 and map location in Figure 3). Tektonik is a complex (multi-rotational) and flow-like landslide with a length of more than one kilometer in an E-W direction. This landslide, initiated on 4 July 1992, displaced 2.5 million $\mathrm{m}^{3}$ of material and caused significant environmental damages [6]. The main escarpment is located at an altitude of around $1350 \mathrm{~m}$, while its lower part, divided into two lobes, joins the Mailuu-Suu River at an altitude of around $1000 \mathrm{~m}$. A secondary scarp is located just below the main escarpment. Its activity is controlled by many factors, such as the loess cover in the upper part and the natural groundwater conditions that make it unstable [39]. The main risk for the surrounding population is related to its high river damming potential. This landslide first collapsed massively a few weeks after the earthquake of 15 May 1992, which struck the region with a magnitude of 6.2 [5,26,40,41]. The epicenter of this earthquake was located only $30 \mathrm{~km}$ SSE from the town of Maily-Say. Although the aforementioned earthquake certainly contributed to the development of the Tektonik landslide in combination with the rise of the groundwater table after spring precipitations, one must consider that loss of stability over longer terms was caused by the presence of underground mining galleries [5,42]. In 1994, 2002, and 2005, the massive movements of the Tektonik landslide repeatedly lead to the blocking of the Mailuu-Suu River, forming a dam and causing numerous upstream and later also downstream floods [5]. In 2017, massive failure occurred on Koytash landslide, while the Tektonik landslide had only slightly moved in its upper part. The materials and methods used to show the respective behaviors of the two mass movements are detailed in the following section. 


\section{Material and Methods}

\subsection{Comparison of Multitemporal Digital Elevation Models}

Multitemporal DEMs were used to study the evolution of the topography before and after the reactivation of the Koytash landslide (partly also for the Tektonik landslide). We collected all existing DEMs for this region (i.e., Shuttle Radar Topography Mission (SRTM), SPOT, ASTER, and TanDEM-X DEMs), dating from 2000 to 2011, to characterize the topography prior to the collapse (Table 1). Due to the lack of current (post-failure) DEMs for this region, we had to build a new model based on unmanned aerial vehicle (UAV) images. These images were acquired on the 15th of August 2017, during a field campaign, shortly after the failure of Koytash. In total, 434 high-resolution images were processed using the Agisoft Photoscan ${ }^{\circledR}$ software. After removing all possible artefacts (e.g., excess vegetation), this software triangulates a set of control points (i.e., corresponding features between a minimum of three images) to determine the depth of a point in space relative to the image's 2D plane. Altogether, the control points create a cloud of points that represent the skeleton on which the reconstruction of the DEM is based [43]. Before comparing the DEMs, they were georeferenced in the WGS84 UTM coordinate system, interpolated according to the same grid, and resampled to have an identical spatial extension corresponding to the area surveyed with the UAV. To georeference the DEMs, we collected, during a field campaign in August 2017, 24 Differential Global Positioning System (DGPS) in situ points (with an accuracy of $\sim 5 \mathrm{~cm}$, see location of points in Figure 4). Out of the 24 measured DGPS points, we chose 4 stable positions (outside the failure area) that served as ground control points (GCPs) for the adjustment of the Z-axis. The DGPS altitudes measured for these 4 stable GCPs were compared with the corresponding altitudes for these same GCPs extracted from each DEMs. The relative mean differences in altitude were calculated between the DEMs and the GCPs (see Table A1). For each pixel, the mean differences obtained were added or subtracted from the initial altitudes. These steps were carried out with the ArcMap (10.5.1) version of ArcGIS ${ }^{\circledR}$ (developed by ESRI). In order to detect mass displacements due to the collapse in April 2017, we subtracted the TanDEM-X elevation model (pre-landslide) from the UAV DEM (post-landslide). The TanDEM-X and UAV DEMs have vertical accuracies of $4 \mathrm{~m}$ and $0.62 \mathrm{~m}$, respectively. This technique allowed us to highlight an uplift at the foot of Koytash (accumulation zone) and a subsidence at the crest of the landslide (depletion zone).

Table 1. Properties of the DEMs collected for the Mailuu-Suu area (N41E072) since 2000.

\begin{tabular}{|c|c|c|c|c|c|}
\hline DEM & Date & $\begin{array}{c}\text { Spatial } \\
\text { Resolution }\end{array}$ & $\begin{array}{l}\text { Coordinates } \\
\text { System }\end{array}$ & $\begin{array}{l}\text { Vertical } \\
\text { Datum }\end{array}$ & Source \\
\hline SRTM & 2000 & $\begin{array}{c}30 \mathrm{~m} \\
(1 \text { arc-second })\end{array}$ & WGS84 & EGM96 & $\begin{array}{c}\text { Shuttle Radar Topography } \\
\text { Mission } \\
\text { NASA }\end{array}$ \\
\hline SPOT & 1 April 2006 & $20 \mathrm{~m}$ & WGS84 & EGM96 & Airbus Defence and Space \\
\hline ASTER & 16 March 2011 & $\begin{array}{c}30 \mathrm{~m} \\
\text { (1 arc-second) }\end{array}$ & WGS84 & EGM96 & NASA \\
\hline TanDEM-X & 14 March 2011 & $12 \mathrm{~m}$ & WGS84 & WGS84 & $\begin{array}{c}\text { WorldDEM, DLR \& } \\
\text { Airbus Defence and Space }\end{array}$ \\
\hline UAV & 15 August 2017 & $0.2 \mathrm{~m}$ & WGS84 & - & $\begin{array}{c}\text { Georisk Laboratory, } \\
\text { ULiège }\end{array}$ \\
\hline
\end{tabular}



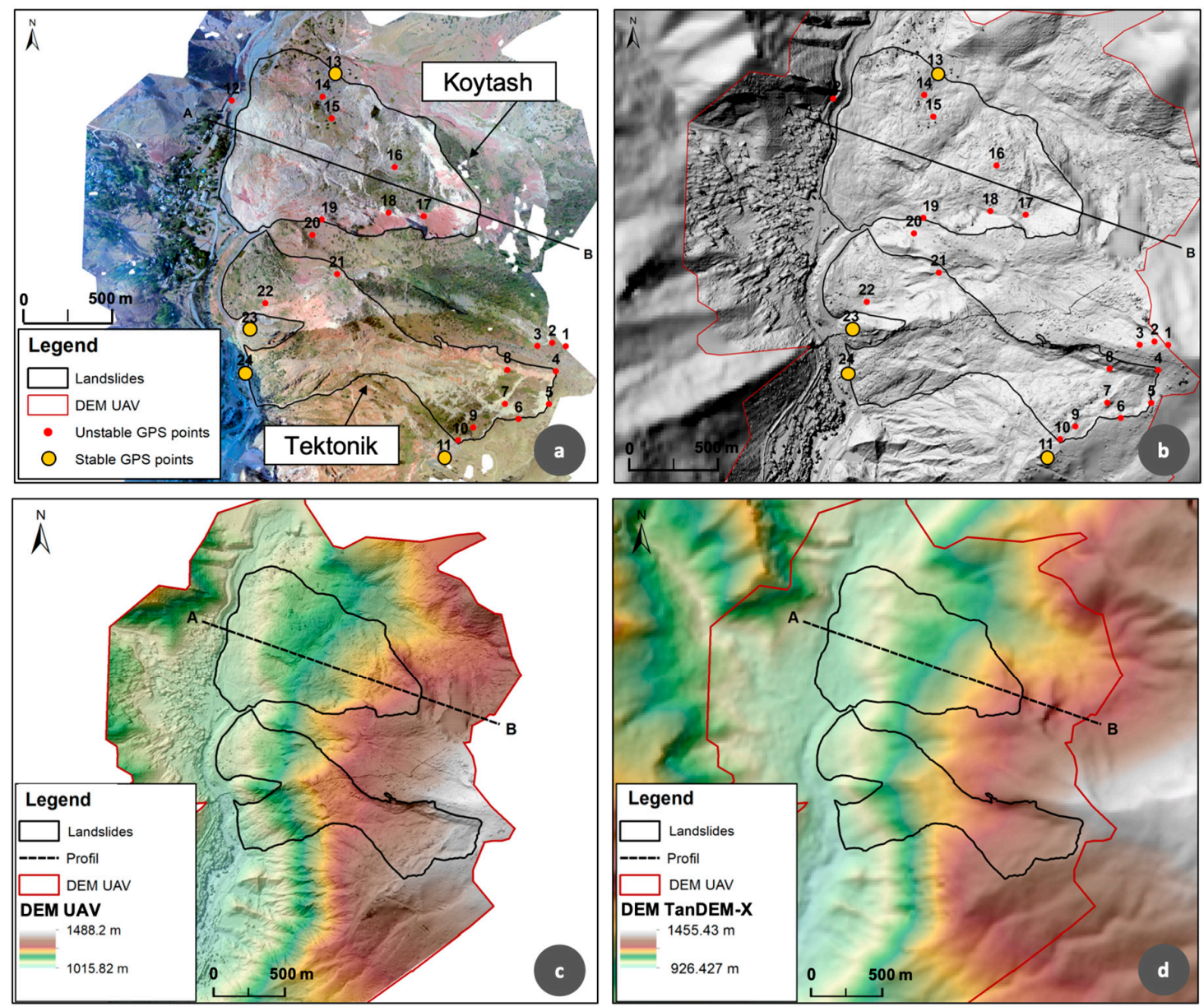

Figure 4. Maps of Koytash and Tektonik landslides. (a) Location of the Differential Global Positioning System (DGPS) points represented on the unmanned aerial vehicle (UAV) orthophoto. Stable points are shown in yellow while unstable points are in red. (b) Location of the DGPS points on the combined TanDEM-X (outer part) and UAV (central part, within light red outline) hillshades. (c) UAV DEM of the Mailuu-Suu area represented in transparency (30\%) on the relative hillshade (spatial resolution of $0.2 \mathrm{~m}$ ). (d) TanDEM-X DEM of the Mailuu-Suu area represented in transparency (30\%) on the relative hillshade (spatial resolution of $12 \mathrm{~m}$ ). The landslides boundaries are drawn in black and the spatial extension of the UAV model is indicated in red.

\subsection{Radar Remote Sensing}

The basic principles of InSAR rely on SAR systems sending radar signals to the Earth that are then reflected by the ground surface to the satellite. InSAR refers to several methods based on phase measurements $[44,45]$. The phase, measured for the return signal to the satellite, depends on the distance between the specific target and the satellite. The launch in 2014 of the first Earth Observation Satellite from the Copernicus program of the European Space Agency (ESA), Sentinel-1, brought new open access possibilities to monitor natural processes such as landslides. In this study, D-InSAR enables detecting displacements from the Copernicus Sentinel-1 sensors to the scattering target along the LOS of the satellite (Figure 5) [46]. 


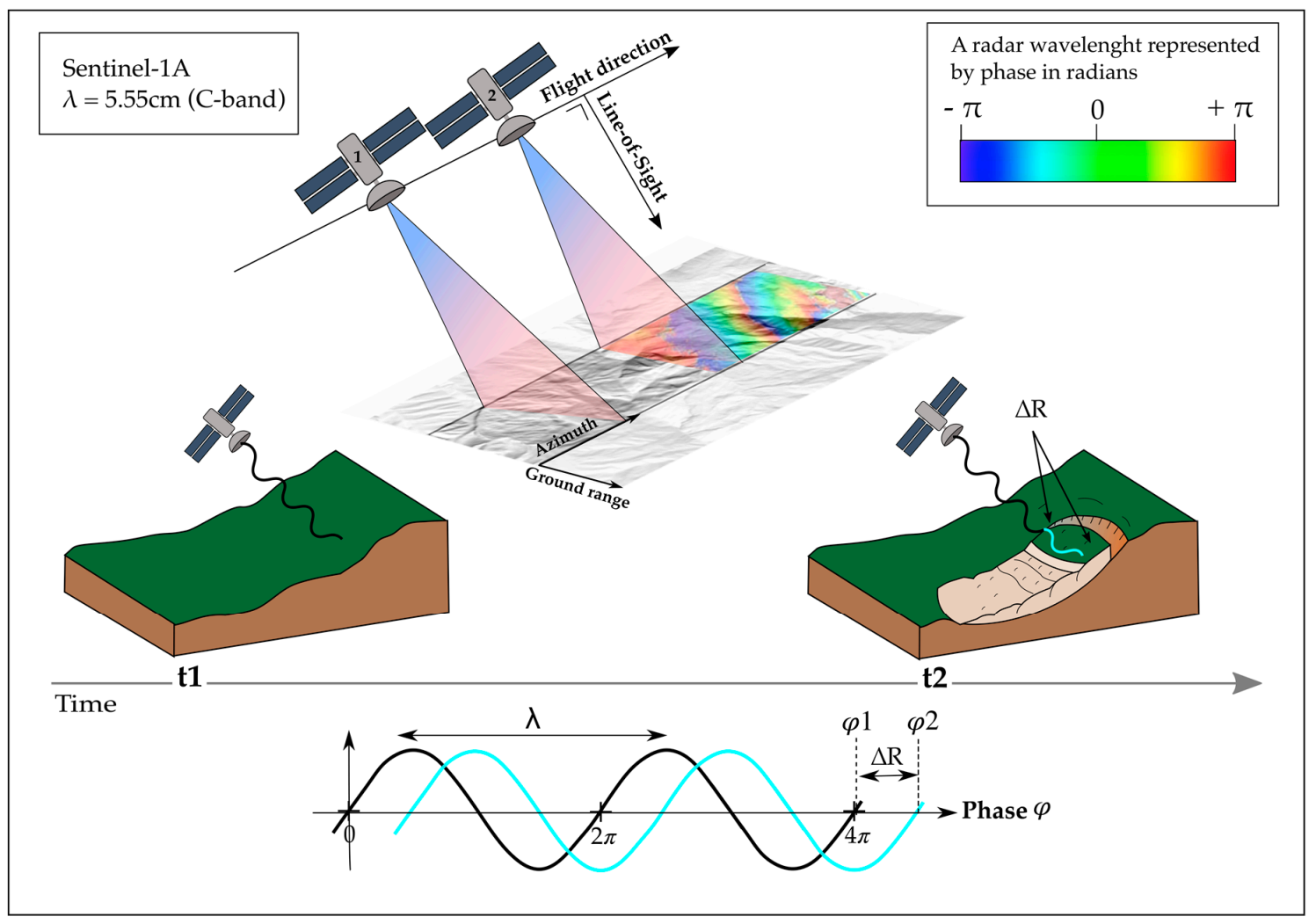

Figure 5. Geometry of a SAR image and principle of D-InSAR during two successive passes $\left(t_{1}\right.$ and $\left.t_{2}\right)$ of the satellite over the same area, in this case, respectively, before and after a landslide activation (or a reactivation as for Koytash) and generation of an interferogram; $\Delta \mathrm{R}=$ difference of distance travelled by the phase $\varphi ; \lambda=$ wavelength of the sensor (modified from the Geoscience Australia [47]).

Measuring displacements with InSAR can be done using either descending or ascending geometry. When studying a roto-translational landslide such as Koytash, the movements are mainly perpendicular to the surface at the top and the foot of the landslide. As Sentinel- 1 is a right-looking satellite, we chose the ascending geometry for which the LOS is almost parallel to the main rotational deformation and thus more or less perpendicular to the slope (Figure 5). Thus, relatively to the landslide surface, a subsidence is a downward negative displacement, while an uplift is positive. However, velocities are projected according to the general downhill movement of the landslide.

This method is based on the difference of phase recorded when a displacement occurs between two SAR acquisitions. The repeat cycle of the SAR satellite, in this case Sentinel-1, measures a phase value for each distinct pixel of the target area at two different times (e.g., every 6 days with the two operational Sentinel-1A and Sentinel-1B satellites). The phase difference, also called interferometric phase $\left(\Delta \varphi_{\text {int }}\right)$, is expressed by

$$
\Delta \varphi_{\text {int }}=\varphi\left(\mathrm{t}_{1}\right)-\varphi\left(\mathrm{t}_{2}\right)=\Delta \varphi_{\text {def }}+\Delta \varphi_{\text {orb }}+\Delta \varphi_{\text {topo }}+\Delta \varphi_{\text {atm }}+\Delta \varphi_{\text {noise }}
$$

where $\varphi\left(t_{1}\right)$ and $\varphi\left(t_{2}\right)$ are the SAR phase values at $t_{1}$ and $t_{2} ; \Delta \varphi_{\text {def }}$ is the phase difference related to the ground displacement in the LOS direction; $\Delta \varphi_{\text {orb }}$ is the orbital geometry variations of the satellite between two acquisitions due to the Earth curvature; $\Delta \varphi_{\text {topo }}$ is the topographic component; $\Delta \varphi_{\text {atm }}$ is the atmospheric contribution (related to a potential modification of the signal propagation in the atmosphere); and $\Delta \varphi_{\text {noise }}$ is the background noise resulting from changes in soil diffusion properties, changes in thermal properties of the atmosphere, and possible errors of co-registration [9]. As the atmospheric component acts at a regional scale, the impact of $\Delta \varphi_{\text {atm }}$ can be ignored when focusing on local displacements. In the case of D-InSAR, the topographic component is removed 
by using a pre-existing DEM to leave only the phase difference associated to the displacement [48]. Although, a DEM sampled at SAR resolution would be necessary to completely remove the topography, lower resolution global DEMs, available in open access, are suitable when studying ground deformations (e.g., SRTM DEM [49-55]). The orbital contribution can be removed as we selected SAR images acquired along a same orbit, which we assume to be correctly georeferenced.

The processing chain we used for the generation of interferograms is synthetized as a flowchart in the Appendix A, Figure A1. The open access Sentinel Application Platform (SNAP) software acquired via the Copernicus Open Access Hub provided by ESA, was used to process Sentinel-1 Single Look Complex (SLC) images. After being imported, the data was co-registered so that the master image, taken as a reference, and the slave images coincide. After this essential step, a preliminary interferogram was generated. Then, in order to preserve solely the phase component related to variations in the optical path, we subtracted the topographic contribution from the interferogram [56]. To do this, the DEM of the Shuttle Radar Topography Mission (SRTM, $30 \mathrm{~m}$ resolution), was subtracted from the preliminary product. During the last decades, many researchers used SRTM DEMs for their InSAR processing [49-55]. As the same topographic reference (DEM) is used for each pair of images, it does not affect the measurement of relative displacements of a few centimeters. Subsequently, the Goldstein Phase Filtering, Multilooking, and Range-Doppler terrain correction steps were applied to reduce noise, resize pixels in square format, and correct geometric distortions linked to the topography. The phase of the differential interferogram, initially expressed in radians, was then unwrapped to convert it into ground displacements. As a starting location for the unwrapping process, we chose a reference DGPS point (\#23) situated in a stable and coherent area outside the boundaries of the landslides (see Figure $4 \mathrm{a}$ and Table A1). Finally, these displacements along the LOS $\left(\mathrm{D}_{\mathrm{LOS}}\right)$ are calculated using the following equation,

$$
\mathrm{D}_{\mathrm{LOS}}=\frac{\lambda \Delta \varphi \mathrm{def}}{4 \pi}
$$

with $\lambda=$ wavelength of the satellite (i.e., $5.55 \mathrm{~cm}$ for Sentinel-1 C-band radar).

The dataset we used for this analysis consists of SAR satellite images captured between January 2016 and December 2017 over the Mailuu-Suu area (Table 2). We used Sentinel-1A images taken in the Interferometric Wide swath mode (IW), whereas Sentinel-1B images were unavailable over the area. As the Koytash landslide is facing west, we used ascending geometry for the SAR images acquired in the Terrain Observation by Progressive Scans (TOPSAR) mode. In total, 50 SLC products were analyzed to estimate the displacement rate before, during, and after the collapse of Koytash.

Table 2. Properties of the Sentinel-1A SAR images collected for the Mailuu-Suu area and used in this study.

\begin{tabular}{cc}
\hline Sentinel-1A & Properties \\
\hline Microwave band (wavelength) & C-band $(5.55 \mathrm{~cm})$ \\
Imaging mode & TOPSAR \\
Orbital geometry & Ascending \\
Acquisition mode & IW \\
Spatial resolution & $5 \mathrm{~m} \times 20 \mathrm{~m}$ \\
Acquisition date & $29.1^{\circ}$ to $46^{\circ}$ \\
Incidence angle & SLC \\
Type & 1 \\
Treatment level & VV \\
Polarization & From January 2016 to 317 \\
\hline
\end{tabular}

On top of $\mathrm{D}_{\mathrm{LOS}}$ measurements, we calculated average velocities along the LOS $\left(\mathrm{V}_{\mathrm{LOS}} ; \mathrm{cm} /\right.$ year $)$ between 23 January 2016 and 29 May 2017. This step results from the use of the Multitemporal InSAR Analysis (MTA) processing mode of the FASTVEL algorithm [57]. FASTVEL was recently developed by TRE-Altamira and is available with restricted access on the ESA Geohazards Exploitation Platform (v2) [58]. This specific processing chain allows the creation of maps (in GeoTIFF format) of 
average ground displacement velocities during observation periods (in $\mathrm{cm} /$ year) based on the Persistent Scatterer Interferometry (PSI) technique [59]. The FASTVEL algorithm employs ENVironment SATellite (ENVISAT), Advanced SAR (ASAR), European Remote Sensing (ERS), as well as Sentinel-1 products to identify surface movements from a set of SAR images analyzing the stack of differential interferograms to extract terrain displacement information (e.g., extent and magnitude). Using the MTA mode, a map of the corrected topography (DEM error and reference DEM in meters) in GeoTIFF format (not used in this study) is produced. The main information of PSI products, in the LOS, in which each line of the database will represent one measurement point are delivered in a CSV file [60].

\subsection{Optical Remote Sensing}

We also studied the Koytash landslide using optical remote sensing by calculating the difference in vegetation indices (i.e., NDVI), allowing for the semiautomatic detection of (re)activated zones. We performed this complementary analysis because it enables to overcome certain limitations of D-InSAR, essentially linked to the significant loss of coherence for rapid movements [61,62]. To calculate the NDVIs, we used Pleaide-1A images coming from a single sensor which currently have the highest spatial resolution (Figure 6a). Therefore, this certifies that the bands used for image processing present the same wavelength and spectral response. In order to obtain the best acquisitions to perform the NDVI analysis, we pre-selected all Pleaide-1A images with less than $10 \%$ of cloud cover and chose the pre- and post-images closest to the date of the landslide failure. Accordingly, we compared an image from the 6th of June 2016 (pre-) with one taken on the 1st of October 2017 (post-landslide), both acquired in the descending mode and presenting a spatial resolution of $0.5 \mathrm{~m}$ (Figure $6 \mathrm{~b}, \mathrm{c}$ ). We co-registered the raw images before comparing them to one another $[23,25]$. In addition, the topographic component and possible distortions were corrected (orthorectification). These steps are part of the geometric corrections that were necessary to perform a change detection analysis, obtain better results, and facilitate the interpretation of the Earth surface process $[19,25,63]$.

NDVI is an indicator of vegetation health and biomass that is based on leaf absorption and reflection. During photosynthesis, live leaves mainly absorb incoming solar radiation within the red spectral band while reflecting near-infrared light. Within each spectral band, reflectances are ratios of the scattered over the incoming radiation. NDVI values are calculated using the following equation,

$$
\mathrm{NDVI}=\frac{\left(\rho_{\mathrm{NIR}}-\rho_{\mathrm{R}}\right)}{\left(\rho_{\mathrm{NIR}}+\rho_{\mathrm{R}}\right)}
$$

where $\rho_{N I R}$ and $\rho_{R}$ are the spectral reflectance measurements, respectively, in the near-infrared band (NIR) and in the red band (R). Theoretically, NDVI values range between -1 and $+1[20,61]$. Negative values correspond to areas with water, ice, or snow, which have higher $\rho_{R}$ than $\rho_{N I R}$. Barren surfaces (rock or soil) have similar $R$ and NIR reflectances resulting in NDVIs near 0 . Positive values refer to areas with vegetation. Accordingly, low positive values ( 0.2-0.5) represent shrubs or grassland while higher values approaching +1 ( 0.6-0.9) represent luxuriant vegetation likely indicating slope stability [64,65]. This produced monochromatic images (grayscale). To improve the readability of the output image, we decided to modify the color scale (blue-green). Once the NDVIs were obtained for the entire master and slave images, we calculated the NDVI difference using the following equation,

$$
\Delta \text { NDVI }=\text { NDVI2017 }- \text { NDVI2016 }
$$

Computed in ArcMap, this method consists in subtracting, pixel-by-pixel, the NDVI values of the pre-landslide image from the post-landslide image. The result is a monochromatic image, this time with values ranging from -2 to +2 . All the steps described hereinabove, except the latter, were achieved using the ENVI software (version 5.4.1) developed by Harris Geospatial. 


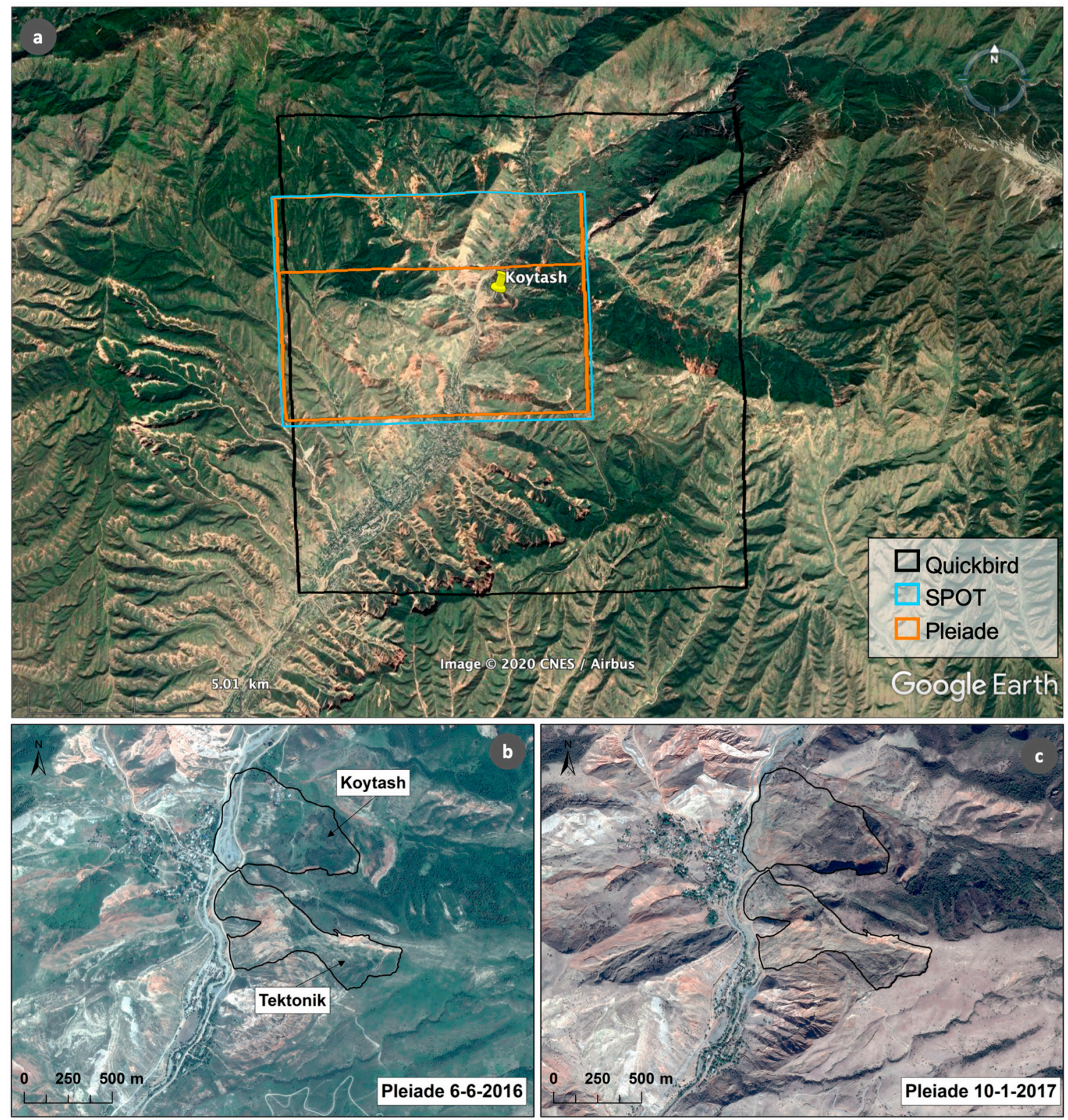

Figure 6. (a) Location of the main optical images over the Mailuu-Suu area in Google Earth. (b) Pleiades image of the 6th of June 2016 with the Koytash and Tektonik landslides (underlined in black). (c) Pleiades image of the 1st of October 2017.

\subsection{Meteorological Data}

In order to have a deeper understanding of the environmental conditions in which Koytash was massively reactivated during spring 2017, we performed a rudimentary meteorological analysis. The only in situ data available came from the Ak-Terek weather station, located about $30 \mathrm{~km}$ east of the Koytash landslide at an altitude of $1772 \mathrm{~m}$. Despite the potential bias linked to the distance from our study site, we preferred to use in situ data (including rainfall, snow depth, and temperature), as previous studies highlighted the important underestimation of satellite rainfall data [66]. Since 1934, temperature, rain, and snow precipitation data have been recorded daily by the station. To identify and highlight potential triggers to the reactivation of the Koytash landslide, we examined the meteorological records between the 1st of January 2011 and the 31st of December 2017. Unfortunately, in situ rainfall data was missing between August 27th, 2014 and December 1st, 2015 as well as from January to June 
2016. This lack of records might be explained either by intense snowfall precipitations or by an error due to a deficiency of the station. After collecting and compiling the significant weather-related data, we produced relevant graphs showing both the daily and monthly evolution of meteorological factors prior and after the collapse of Koytash in April 2017; they are shown at the end of the next section.

\section{Results}

\subsection{Differences between Pre- and Post-Failure Topography}

In order to observe the effects of rapid movements on the topography of the Koytash landslide during its reactivation, we compared all previously mentioned DEMs. The smaller deformations prior to failure will be analyzed via D-InSAR processing in the next sub-section. Figure 7a compiles all DEMs, after the application of corrective factors (see Section 3.1), along the A-B profile of the main axis of the Koytash landslide. According to the DGPS in situ data, the TanDEM-X from 2011 represents the best topographic fit with a calculated relative mean difference of $4.55 \mathrm{~m}$ in altitude (see Table A1). Thus, this TanDEM- $X$ was compared with the post-failure UAV DEM for this analysis.

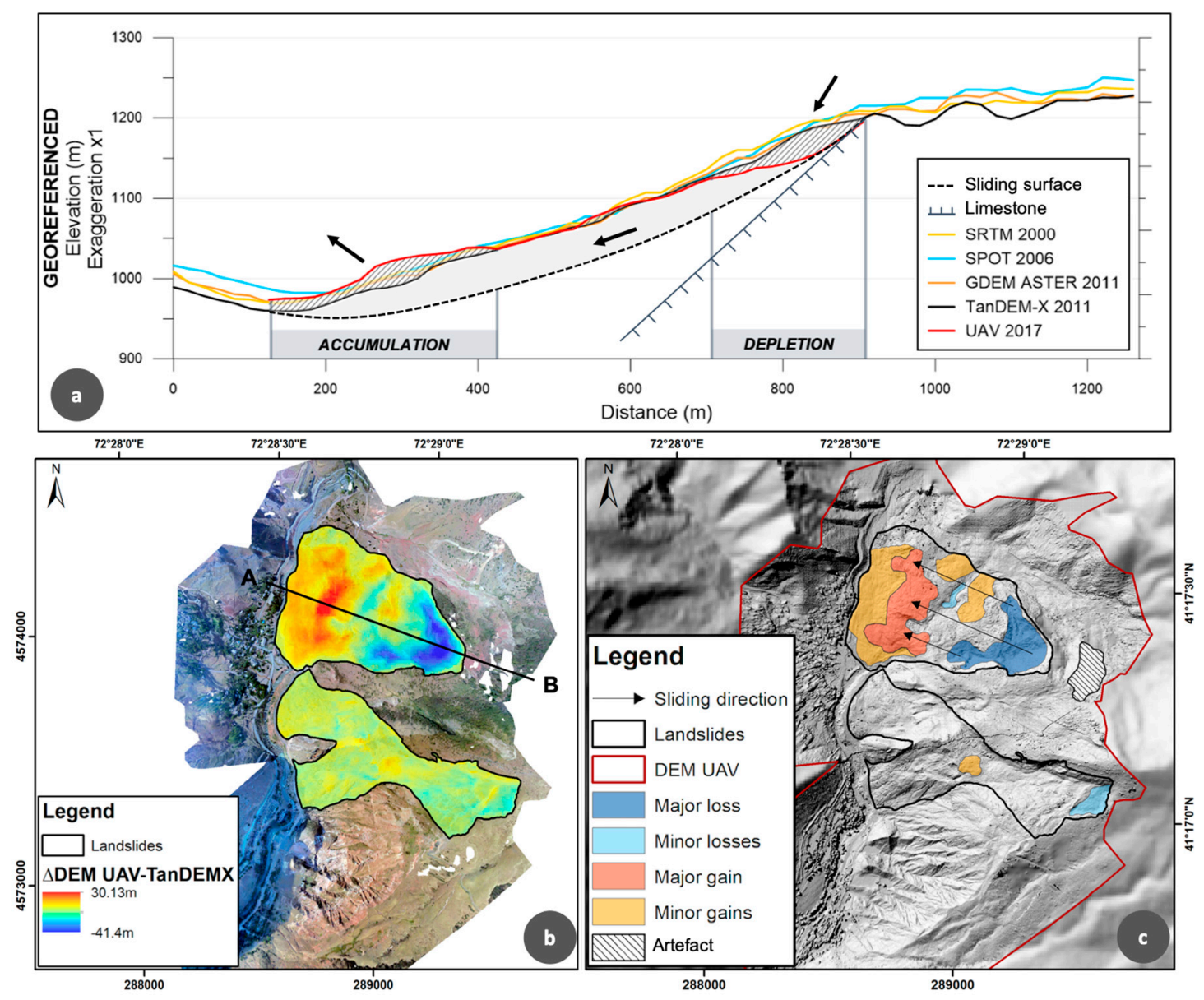

Figure 7. (a) A-B profiles of the DEMs, along the main axis of Koytash landslide, georeferenced according to the DGPS stable points and acquired for the Mailuu-Suu area (N41E072) since 2000. The black arrows indicate the roto-translational movement of the landslide. (b) Difference in topography for the Koytash and Tektonik landslides resulting of the operation $\left[\triangle \mathrm{DEM}=\mathrm{DEM}_{\mathrm{UAV}}-\mathrm{DEM}_{\mathrm{TanDEM}-\mathrm{X}}\right]$. The contours of the landslides are underlined in black. (c) Delimitation of the loss and gain zones (major and minor) as well as the spatial extension of the UAV DEM (red line). The black arrows display the projected sliding direction. The delimited artifact refers to a zone with missing data probably due to an excess of vegetation. 
As shown in Figure 7b, the difference of DEMs revealed the displacement of sediments during the reactivation episode of April 2017. Several zones were identified: a depletion zone, located in the upper part of the Koytash landslide and indicating the removal of rocky material along the scarp, and an accumulation zone, situated near the toe of the landslide body where more than $30 \mathrm{~m}$ of rocks were uplifted. The two aforementioned zones were then mapped according to the degree of surface level change (i.e., minor and major, see Figure 7c). The hatched area on Figure 7c represents an artifact that could potentially be related to an excess of vegetation. The collapse along the scarp caused a downward displacement of the material resulting in an uplift and the accumulation of sediments at the foot of the landslide, which partially blocked the Mailuu-Suu River. This analysis also highlighted a minor depletion zone on the top and a small accumulation zone in the middle of the neighboring landslide, Tektonik. These results are in accordance with the roto-translational nature of the landslide movement as well as with the in situ observations described in Section 2.

\subsection{Landslide Displacements from D-InSAR Analysis}

On the basis of the 50 available Sentinel-1A radar images, we created 46 differential interferograms. Three periods (pre-, intra-, and post-reactivation), characterized by an interval of 12 days, were considered: 2-14 August 2016, 18-30 March, 2017 and 9-21 August 2017. The three unwrapped differential interferograms are presented in Figure 8 to estimate displacements at pre-, intra-, and post-sliding periods. The phase unwrapping measures values initially expressed in radians $[0,2 \pi]$ that were converted in $\mathrm{D}_{\mathrm{LOS}}(\mathrm{cm})$ measurements. In order to obtain consistent and comparable results between the three considered periods, the process of phase unwrapping was carried out according to the four known stable DGPS points $(11,13,23$, and 24; see Figure 4).

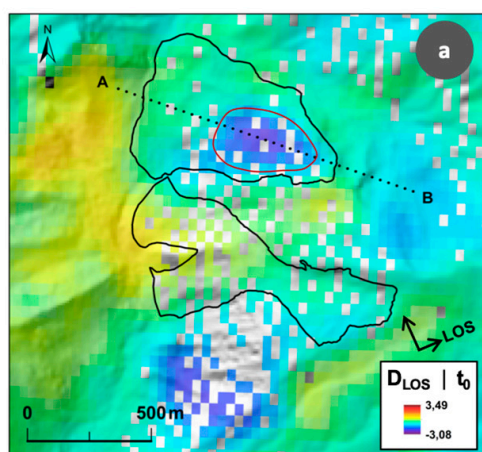

August 2016

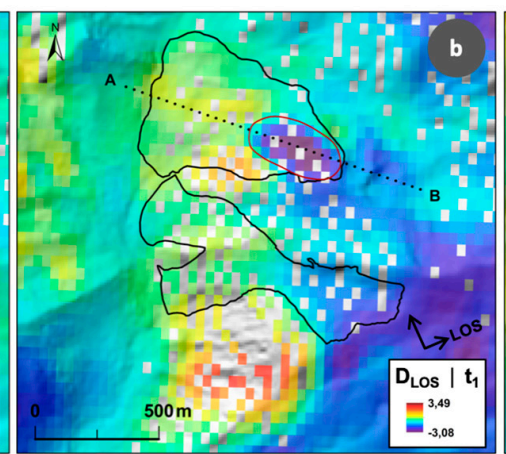

March 2017

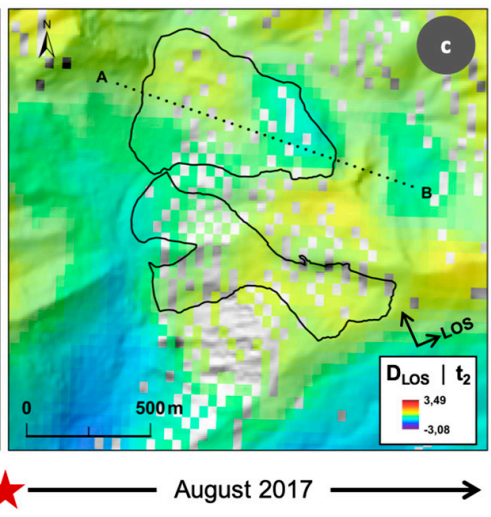

Figure 8. $\mathrm{D}_{\mathrm{LOS}}$ (in $\mathrm{cm}$ ) observed for the Koytash and Tektonik landslides in Maily-Say (a) $\mathrm{D}_{\text {LOS }}$ between 2 August and 14 August 2016 - $\mathrm{t}_{0} ;$ (b) D LOS between 18 March and 30 March 2017- $\mathrm{t}_{1} ;(\mathbf{c}) \mathrm{D}_{\mathrm{LOS}}$ between 9 August and 21 August 2017- $t_{2}$. The negative $D_{\text {LOS }}$ (in blue) and positive (in red) indicate respectively the points moving away and approaching the radar sensor. The interferograms are displayed in transparency on the TanDEM-X hillshade. On these interferograms, the thin black line presents the boundaries of the landslide and the dotted line corresponds to the A-B profile for which the unwrapped phase values were extracted. The deformation fields within the landslides are outlined in dark red. The red star represents the reactivation in April 2017.

The interferometric phase result, transformed into LOS displacements $\left(\mathrm{D}_{\mathrm{LOS}}\right)$, displays positive values (in red) when going towards the satellite and negative values (in blue) when moving away (see results for $t_{0}$ in Figure $8 \mathrm{a}$ ). From the perspective of the landslide surface, a subsidence is negative while an uplift is positive. The Koytash landslide presents, in its upper part, an oval-shape deformation field with a diameter (along the A-B profile) of approximately $400 \mathrm{~m}$. This deformation, extending from west to east, is characterized by negative displacements. Moving away from the central point of this anomaly, for which the $\mathrm{D}_{\mathrm{LOS}}$ reached $1.1 \mathrm{~cm}$ of displacement away from the sensor over 12 days, 
the $\mathrm{D}_{\mathrm{LOS}}$ values tend towards 0 in the middle part of the landslide body. The displacements are negative inside the landslide boundaries and therefore represent a predominantly vertical movement of subsidence close to the scarp area.

The second unwrapped phase result (Figure $8 b, t_{1}$ ) is based on SAR acquisitions taken one month before the recent reactivation. For Koytash, the conditions are similar to the differential interferogram of August 2016 with the presence of an ellipsoidal anomaly upstream of the landslide while the deformation field moved slightly upwards, following the shape of the main escarpment, with a slight increase in the displacement amplitude. At $t_{1}$ (March 2017), the maximum $\mathrm{D}_{\mathrm{LOS}}$ measured at this location reached $-1.5 \mathrm{~cm}$, while the foothills of the landslide are characterized by low but positive values, nearing 0 . Previously negative, these values demonstrate the transition from a subsidence to an uplift at the toe of the landslide.

The third interferogram (Figure 8c, $t_{2}$ ), created from the SAR acquisitions of August 2017, differs from the previous ones. Indeed, more than two months after the reactivation of the Koytash landslide, the movement gradually became stationary. The deformation pattern visible on the previous interferograms is no longer observed as the collapse has caused a sharp decrease in its activity. The obtained $D_{L}$ LS values are between $-0.17 \mathrm{~cm}$ in the depletion area near the scarp and $0.15 \mathrm{~cm}$ in the foothills.

$\mathrm{V}_{\mathrm{LOS}}$ maps showing the entire spectrum of measured velocities as well as velocities with values strictly greater than $1.5 \mathrm{~cm} /$ year are presented in Figure 9a,b, respectively. In the study zone, the areas recording the highest $\mathrm{V}_{\mathrm{LOS}}$, (i.e., reaching $4.35 \mathrm{~cm} /$ year) are located at the upper parts of Koytash and Tektonik, during the period between 01-23-2016 and 05-29-2017. The downward movement of the ground surface in the deformation areas of both landslides is represented by positive velocities measured along the LOS. For the period considered, a transition from a positive to a negative mean anomaly exactly under the bottleneck zone is observed on the Tektonik landslide, while for the Koytash landslide the values remain positive or negative but close to 0 for the entire landslide body.

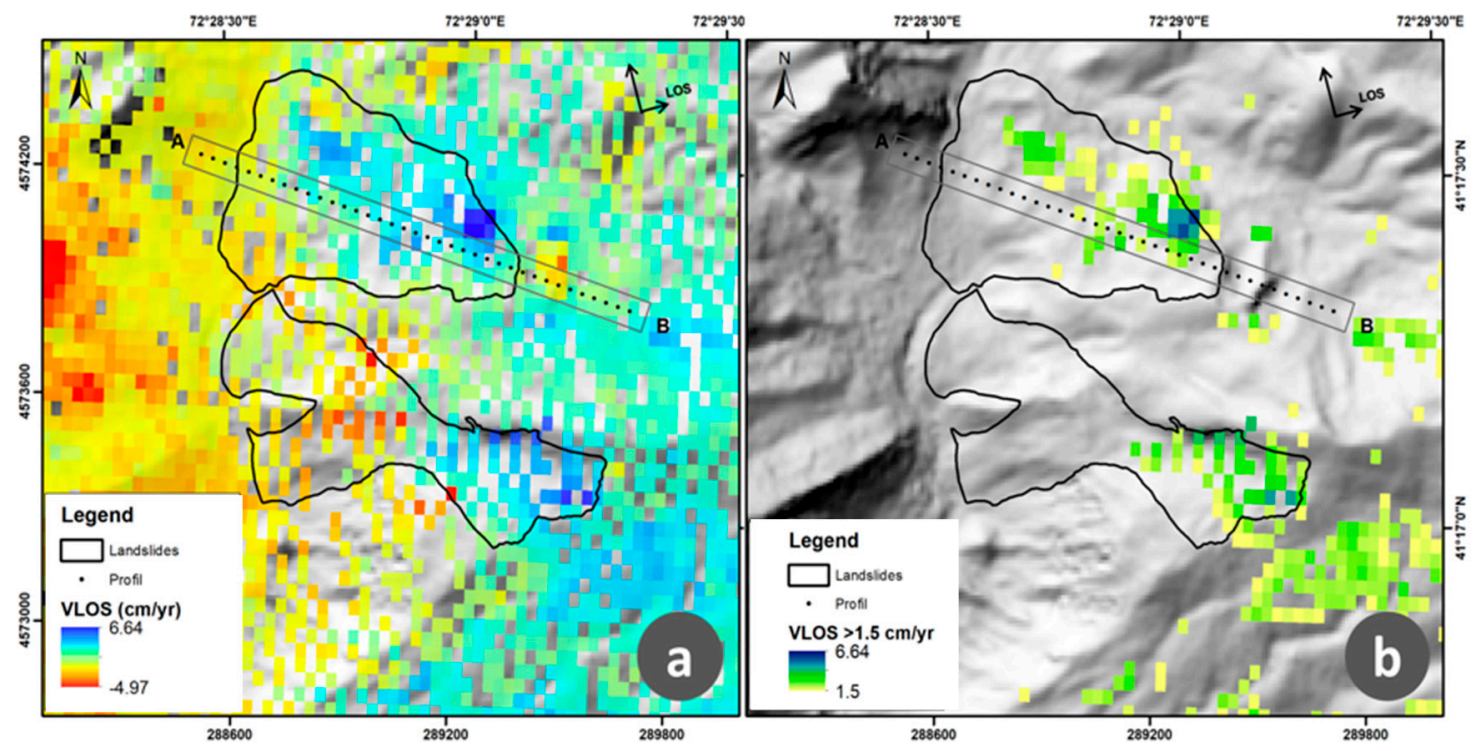

Figure 9. (a) Map of $\mathrm{V}_{\mathrm{LOS}}$ (in $\mathrm{cm} /$ year) resulting from the FASTVEL algorithm. The $\mathrm{V}_{\mathrm{LOS}}$ map is shown in transparency (20\%) on the hillshade based on the 2011 TanDEM-X DEM. The black lines represent the limits of the Koytash and Tektonik, while the dotted line correspond to the central AB profile for which the $\mathrm{V}_{\mathrm{LOS}}$ were extracted; (b) Map of $\mathrm{V}_{\mathrm{LOS}}>1.5 \mathrm{~cm} /$ year displayed on the 2011 TanDEM- $\mathrm{X}$ hillshade.

The $D_{\text {LOS }}$ values of the three differential interferograms (Figure 8a-c) as well as the $V_{L O S}$ values from FASTVEL (Figure 9a) were extracted at 39 points, every $35 \mathrm{~m}$, along three A-B profiles separated by $40 \mathrm{~m}$ as presented in Figure 10. In Figure 10a, the A-B topography profiles show the altitude of 
the landslide slope before (TanDEM-X, 2011) and after the failure (UAV, 2017). These two DEMs help distinguish, from left to right along the A-B profile, the uplift (accumulation zone), the transition zone, and the scarp (depletion zone) of the landslide. The role of this changing topographic profile is to facilitate the planar interpretation of the corresponding $V_{L O S}$ and $D_{L O S}$ values in Figure $10 b, c$, respectively. As a reminder, the DEMs used to show the topography of the landslide in Figure 10a do not correspond to the SRTM DEM used to remove the topographic contribution from the interferometric phase (see Section 3.2). When interpreting these InSAR results, it is important to consider that we measured slow and nonlinear displacements changing over time. Although $\mathrm{D}_{\mathrm{LOS}}(\mathrm{cm})$ and $\mathrm{V}_{\mathrm{LOS}}(\mathrm{cm} /$ year) are covering different periods of time and expressed using different units, they are both calculated based on Sentinel-1A images and thus have the same resolution. In Figure 10b, $\mathrm{V}_{\mathrm{LOS}}$, shown in gray, is calculated between 23 January 2016 and 29 May 2017. The yellow, brown, and blue dots in Figure 10c represent displacements measured at $t_{0}$ (August 2016), $t_{1}$ (March 2017), and $t_{2}$ (August 2017), respectively. Thus, the $D_{\text {LOS }}$ results depict the behavior of the landslide at three different time frames.

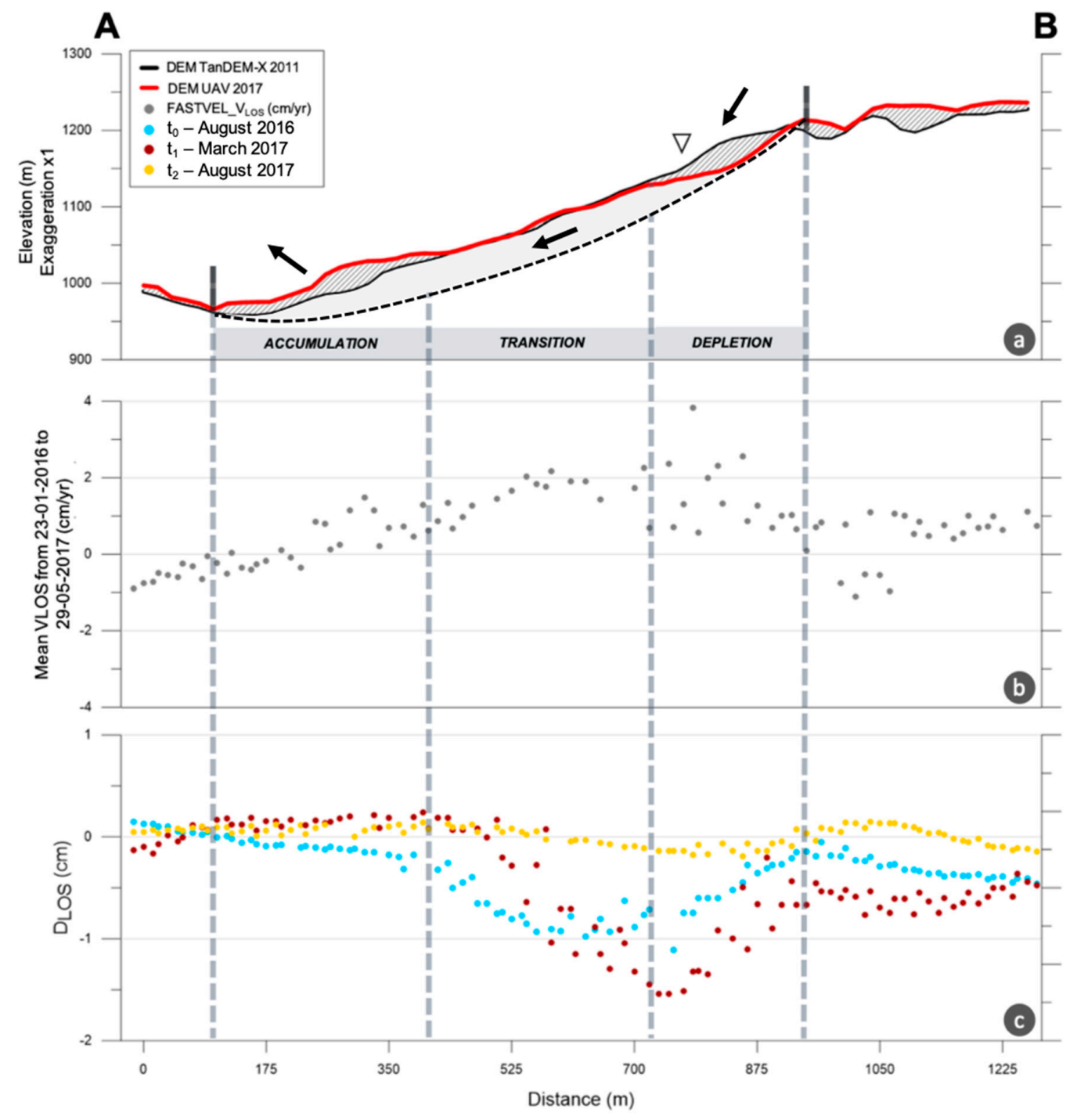

Figure 10. (a) A-B profiles of the altitudes (expressed in $m$, no vertical exaggeration) of the TanDEM- $X$ $\operatorname{DEM}$ (2011, in black) and of the $\operatorname{UAV} \operatorname{DEM}(2017$, in red). The two marks in gray represent the limits of the Koytash landslide; $(\mathbf{b}, \mathbf{c})$ Extraction of the $\mathrm{V}_{\mathrm{LOS}}$ (in $\mathrm{cm} /$ year) and $\mathrm{D}_{\mathrm{LOS}}$ (in $\mathrm{cm}$ ) values for each station on the three A-B profiles separated by $40 \mathrm{~m}$ (see Figure 9). The $\mathrm{V}_{\mathrm{LOS}}$ were calculated for a period between 23 January 2016 and 29 May 2017. The areas of accumulation, transition, and depletion are highlighted and the inverted triangle represents the major peak of displacement rate. 
At the toe of the landslide, the velocities recorded before the accumulation zone, are negative and do not exceed $-0.5 \mathrm{~cm} /$ year, indicating that the area can be considered as stationary (with $\frac{-\lambda}{4 \pi}<$ velocities $<\frac{\lambda}{4 \pi}$ ). Correspondingly, the $\mathrm{D}_{\mathrm{LOS}}$ measured for this zone, at the three periods, are included between -0.2 and $0.2 \mathrm{~cm}$. In the accumulation zone, the $V_{L O S}$ values increase linearly although the displacements are close to $0 \mathrm{~cm} /$ year for all three periods. Overall, as we move along the profile, from the accumulation zone to the depletion zone, we observe higher velocities and an increase in negative displacements at $t_{0}$ and $t_{1}$. Due to the roto-translational nature of Koytash, there are some slow translational movements in the transition zone at $t_{0}$ and $t_{1}$, combined to light downward displacements linked to the continuous creeping of the slope. In the depletion zone, where topographic differences are the highest, the $V_{\text {LOS }}$ values reach maxima, up to $4 \mathrm{~cm} /$ year, with a negative displacement peak of $-1.5 \mathrm{~cm}$ in 12 days for $t_{1}$. Additionally, the slopes of the $D_{\text {LOS }}$ points at each period of time $\left(t_{0}, t_{1}\right.$, and $\left.t_{2}\right)$ reveal the different acceleration intensities. Although all displacements are negative, we notice that the slope steepness deduced by the dots is greater for the $t_{1}$ than for the $t_{0}$ interferogram (see Figure $10 \mathrm{c}$ ). Finally, after the collapse of Koytash $\left(t_{2}\right)$, we notice that the entire slope has more or less stabilized with displacement under $0.5 \mathrm{~cm}$ in both directions.

\subsection{Mapping of Reactivated Zones and NDVI Analysis}

The multitemporal series based on high-resolution optical satellite images is shown in Figure 11. This analysis helps observing the evolution of the landslides since the last inventory, based on the Quickbird image acquired in 2007, carried out by Schlögel et al. [23]. Figure 11 gathers six optical images acquired for the study area: Quickbird of 26 June 2007 (Figure 11a); Quickbird of 2 July 2013 (Figure 11b); SPOT6 of 1 April 2014 (Figure 11c); SPOT7 of 11 April 2015 (Figure 11d); SPOT6 of 9 April 2017 (Figure 11e); and SPOT6 of 31 April 2017 (Figure 11f). Taking into consideration the seasonal effect, the deformations zones, visible on this sequence of images, seem to have remained generally stable until 2015, showing several zones of old-growth vegetation. In Figure 11e, we observe that on 9 April 2017, the Tektonik landslide had already started to slide, while Koytash collapsed on the 22nd of April 2017, blocking the Mailuu-Suu River. Although less spectacular than Koytash, the images of 9 April 2017 and 31 May 2017 reveal the failure of the upper part of Tektonik.

Figure 12 illustrates NDVI values pre- (a) and post-landslide reactivation (b) as well as the NDVI difference between the two periods (c). In Figure 12c, the bright zones represent areas which recorded a vegetation loss between 2016 and 2017, while the darker zones indicate a gain of vegetation or no visible change. The bright areas in Figure 12c may result from the reactivation process that occurred between the two acquisitions, causing the collapse of several existing landslides. The areas reactivated in 2017, mapped by comparing the 2016 and 2017 images are shown in red in Figure 12 to demonstrate the equivalence between these landslide limits and the results obtained semi-automatically by calculating the difference in NDVI. This analysis identified the collapse zones of both Koytash and Tektonik. The lighter areas outside the landslide limits are probably linked to high seasonal variability in the vegetation cover between the end of spring (in June) and the end of summer (in October) when cloud free images were available. 

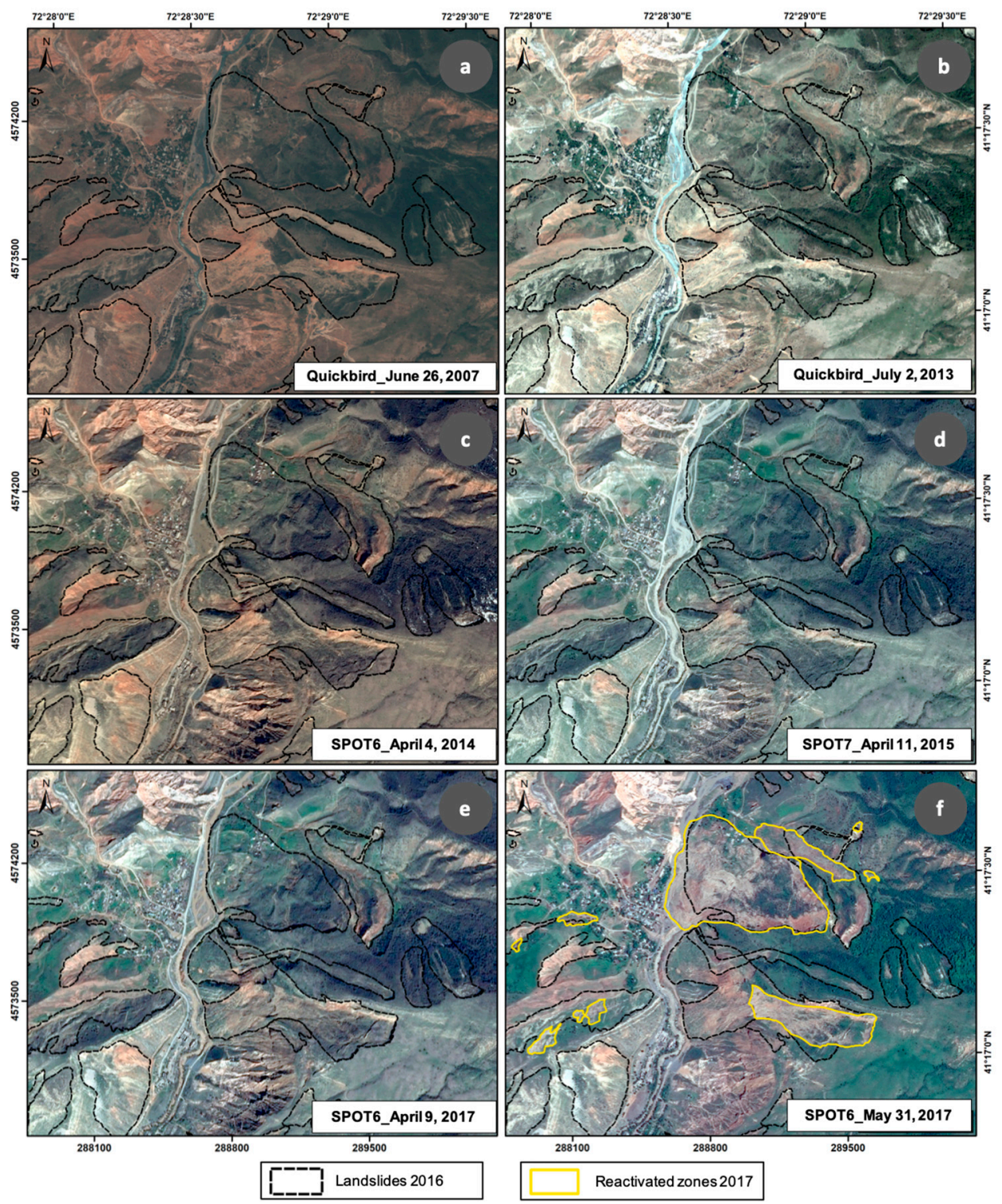

Figure 11. Multitemporal optical analysis of Maily-Say landslides since 2007. This time series was carried out using the latest inventory of landslides to date based on the mapping of a Quickbird image from 26 June 2007 [37]. The landslide boundaries mapped in 2016 are represented by dashed black lines while the reactivated areas are indicated in yellow: (a) Quickbird of 26 June 2007; (b) Quickbird of 2 July 2013; (c) SPOT 6 of 1 April 2014; (d) SPOT 7 of 11 April 2015; (e) SPOT 6 of 9 April 2017; and (f) SPOT 6 of 31 May 2017. 


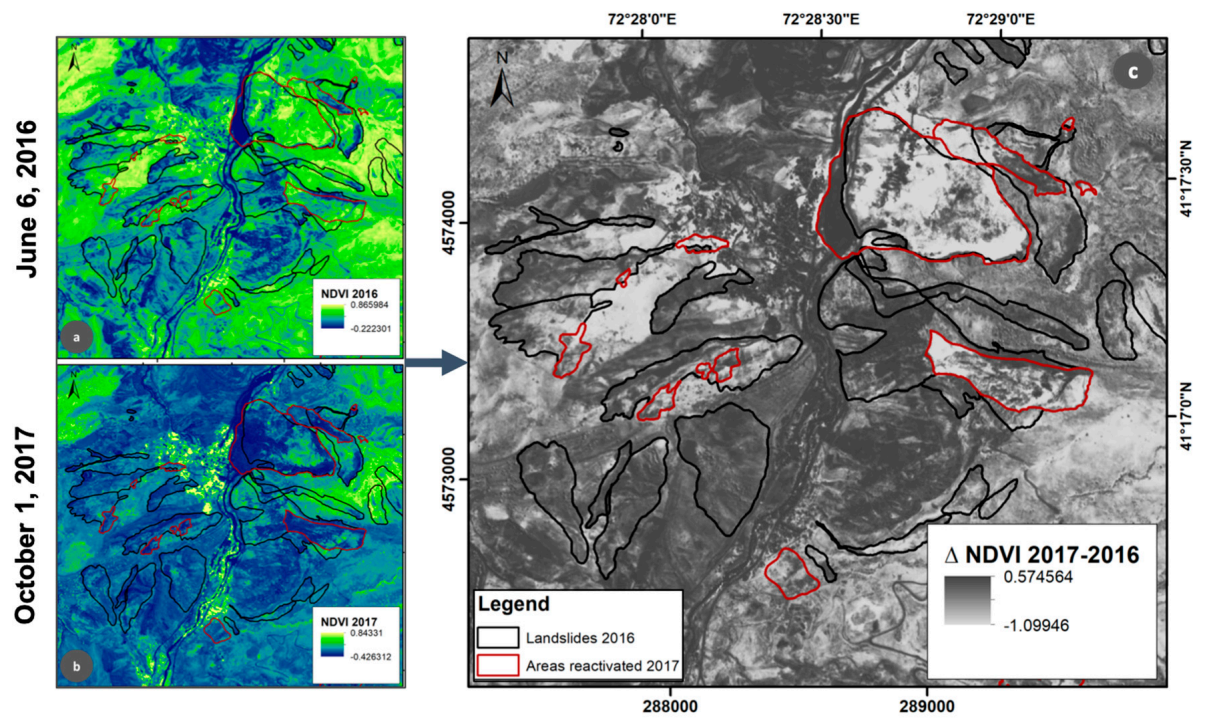

Figure 12. Difference of NDVI calculated for Pleiades images; (a) NDVI calculated for the Pleiades image of June 06, 2016; (b) NDVI calculated for the Pleiades image of October 01, 2017; (c) Difference of NDVI between 2017 and 2016. The limits of the 2016 landslides are outlined in black and the reactivated areas between the two acquisitions in red. The light areas (negative) represent significant land use changes and the dark gray areas (positive) indicate the fragments that remain almost unchanged (even with growing vegetation).

\subsection{Identification of the Meteorological Triggering Factors}

A meteorological analysis was performed to identify the triggering factors contributing to the reactivation of Koytash. We calculated total cumulative precipitations from 2011 to 2016, as well as the total precipitations for 2017, to detect a potential variability in rainfall that might be at the origin of the collapse of the Koytash landslide. On average, since 2011, total annual precipitations reached $1460.5 \mathrm{~mm}$, while only $877.4 \mathrm{~mm}$ where recorded in 2017 . However, despite the fact that 2017 was drier and hotter than previous years, half of the annual rainfall recorded in 2017 fell between March and April (i.e., $414.2 \mathrm{~mm}$ ), just before the reactivation episode (Figure 13). We also observed that the month of April 2017 recorded the fourth highest precipitation peak since January 2011.

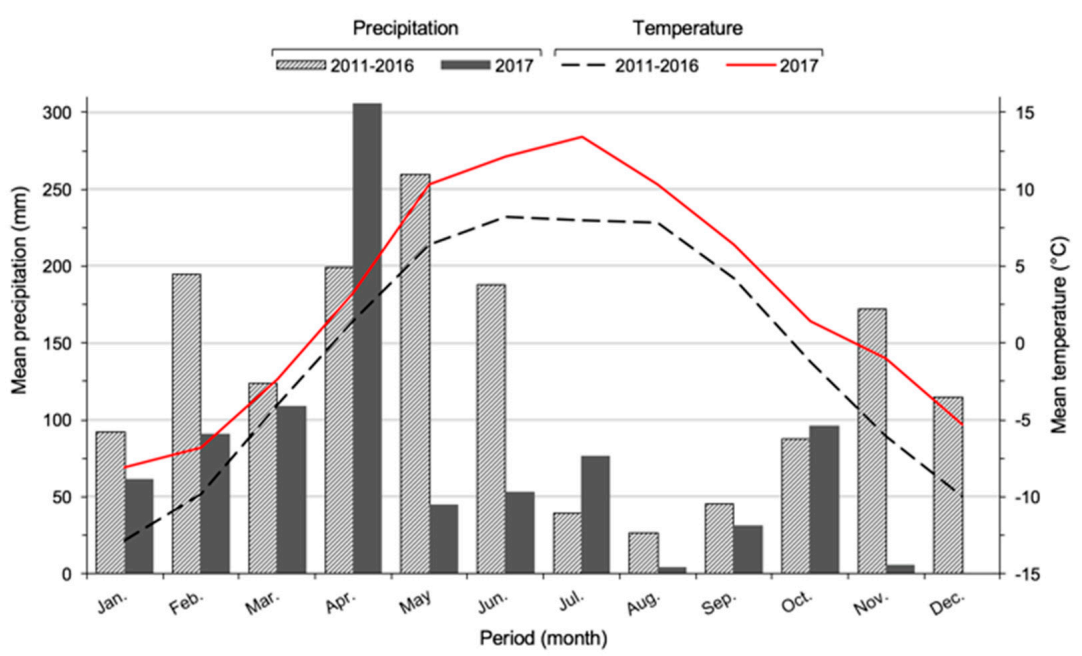

Figure 13. Comparison of precipitation and temperature for the year 2017 (dark gray) versus precipitation and temperature for a period from 2011 to 2016 (hatched) based on in situ data from the Ak-Terek station (located at a higher altitude than the Mailuu-Suu River slopes, at about $1800 \mathrm{~m}$, where the temperature is about $4{ }^{\circ} \mathrm{C}$ lower than in the Mailuu-Suu region). 
When focusing on the meteorological conditions in March and April 2017, we notice that the daily temperature gradually increases from March to April (Figure 14). Consequently, the snow cover decreased progressively during March and disappeared completely before mid-April, about ten days before the collapse. Additionally, precipitations increased starting from 27 March 2017. Three main peaks stand out, on April 3, 13, and 22, with daily precipitation greater than $40 \mathrm{~mm}$. The action of water from the intense rain precipitations in April, especially the peak on 22 April 2017 (52 mm), as well as the rapid snow melting, represent important triggering factors leading to the reactivation of the Koytash landslide.

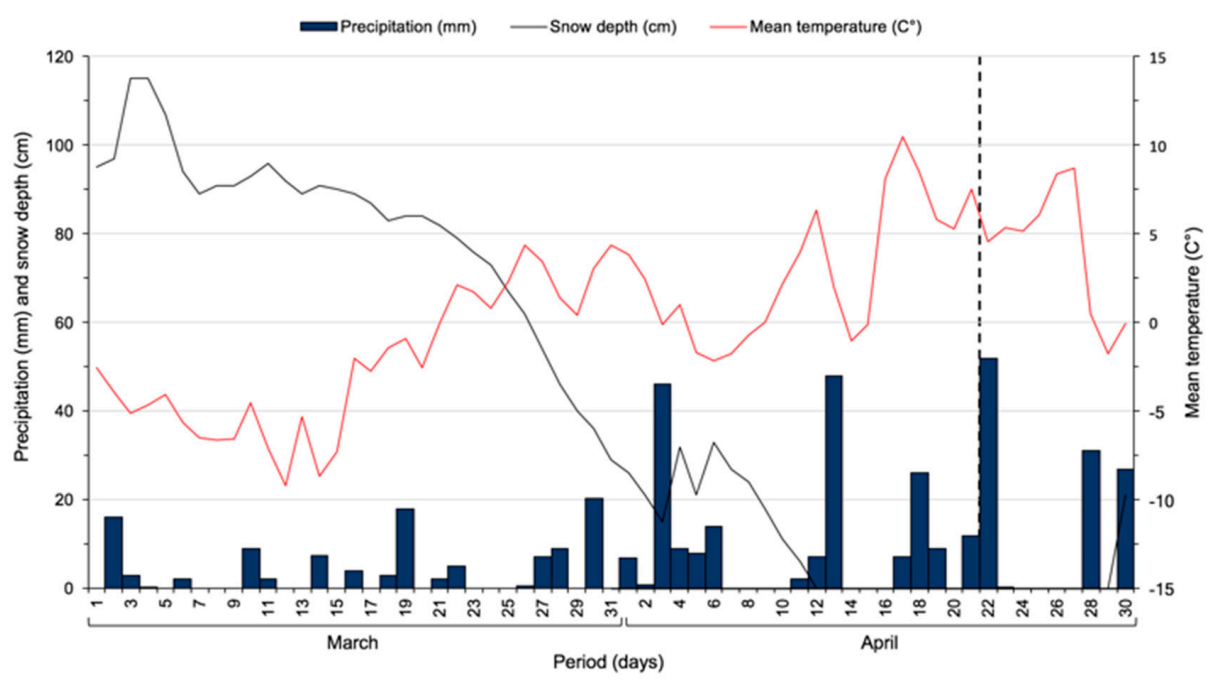

Figure 14. Precipitation (in blue), snow depth (in black) and daily temperature (in red) recorded at the Ak-Terek weather station for the months of March and April 2017. The dotted line represents the moment when Koytash was reactivated.

\section{Discussion}

In Central Asia, numerous studies conducted on mass movements have previously demonstrated the high landslide hazard level of Kyrgyzstan [6]. In 2015, as part of a large-scale geohazards analysis, Havenith et al. [27] performed an extensive landslide susceptibility mapping of the Tien Shan mountain range. Previous studies identified the Mailuu-Suu Valley as one of the regions particularly prone to slope instabilities [3]. Both studies also confirmed that the number of landslides is increasing in this region, with a predominance of the reactivation and enlargement of existing landslides. These mass movements are likely to grow or merge with neighboring landslides when reactivating.

In this study, we used different types of satellite data to investigate the recent reactivation of two of the largest landslides of the Mailuu-Suu Valley, Kyrgyzstan. The Koytash and Tektonik landslides represent a major threat for the local populations due to their recurrent past reactivations, the presence of numerous neighboring nuclear waste tailings, and the risk of damming the Mailuu-Suu River [34]. Although former remote sensing studies in the Mailuu-Suu Valley used satellite data to identify landslides through change detection methods [4,23], this study brings a new dimension by using modern techniques, such as InSAR analysis and UAV imagery, to measure displacement rates and detect deformation zones.

D-InSAR was used to detect slow displacement rates of Koytash and Tektonik one year before their reactivation. In 2015, Teshebaeva et al. [12] performed a D-InSAR analysis to detect slow-moving deep-seated landslides near the town of Uzgen, $90 \mathrm{~km}$ southeast of our study area. Similarly, they highlighted a strong correlation between deformations peaks and precipitations and revealed the continuous activity affecting the slope of the landslides in their area of interest. While they used an L-band Advanced Land Observing Satellite Phased Array type L-band SAR (ALOS PALSAR) data set, we processed the newly available C-band Sentinel-1 satellite images. Although, L-band radar sensors have a longer wavelength (i.e., $\lambda=23.8 \mathrm{~cm}$ ), which partially penetrates surface vegetation 
and allows the measurement of significant $\mathrm{D}_{\mathrm{LOS}}$ over long periods, their temporal resolution is of 46 days [67]. Therefore, due to the low vegetation cover in our study area, we chose the open access C-band SAR images that have only 12 days of repeat cycle (over the Mailuu-Suu area), reducing potential temporal decorrelation in comparison to the former study. Our analysis showed that the upper part of Koytash was the most active with negative $\mathrm{D}_{\text {LOS }}$ values showing an early stage of subsidence along the scarp. Furthermore, the differential interferograms suggest that the reactivations of Koytash and Tektonik were not sudden but resulted from a long-term deformation. This could partly be related to a geological phenomenon called creeping, characterized by a slow downward movement of the soil. It is interesting to note that, during the entire study period, the displacement magnitudes of Koytash were greater than those measured for Tektonik. This result justifies why only the upper part of Tektonik collapsed while Koytash was entirely reactivated. The calculation of $\mathrm{V}_{\mathrm{LOS}}$ also led to this conclusion. When looking at the lower part of Koytash, a transition to very small positive values was detected in March 2017. This may be linked to the fact that the displacements are oriented perpendicularly to the LOS of the satellite, making them difficultly detectable. A few months after the collapse, in August 2017, we noticed that the movement had slowed down, implying a gradual stabilization of the landslide. These results suggest that it took a maximum of four months for the landslide to stabilize after being active for at least nine months prior to the failure. Accordingly, it would be justified to perform a back-analysis of the last decades by using ERS data to produce supplementary interferograms and thus estimate when Koytash's movement was initiated.

One of the most constraining limitations encountered during our D-InSAR analysis was the 1D expression of $\mathrm{D}_{\mathrm{LOS}}$ inducing the systematic underestimation of intensities. Therefore, depending on the field properties, it is only possible to track positive and negative displacements along the LOS of the satellite while deformation in the orthogonal direction is not detectable. In ascending orbital geometry, the observed displacements and velocities are positive when approaching the satellite and negative when moving away from the satellite. Although the multitemporal analysis with the FASTVEL algorithm requires at least 25 images, it is only able to detect mean velocity patterns (or hotspot areas as defined in [59]) that are significantly changing over such a long temporal coverage. Moreover, the velocity rates and directions are evolving overtime in a complex and vegetated terrain meaning that only the relative spatial changes are comparable to detect hazardous areas. To fully apprehend the complex deformation behaviors and facilitate their interpretation, sophisticated multitemporal InSAR techniques with various sensors (multi-angle) [48], ideally combined with in situ measurements, enable to break down the displacements into 3D in order to measure the true direction of the ground movement. Fuhrmann \& Garthwaite [68] demonstrated the advantages of combining LOS measurements from different viewing geometries. Resolving 3D surface displacements would provide an improved overview of the complex geomorphology and dynamic of landslides. It would also be interesting to exploit additional SAR processing chains such as the SBAS (Small BAseline Subset) $[69,70]$ or PSI multi-time series [62,71] to go one step further in multitemporal InSAR analysis. Another frequently encountered error in D-InSAR analysis is related to phase unwrapping and often leads to the misinterpretation of results [72]. In the case of Koytash and Tektonik, several parameters, such as the topography of the region and significant variations in the deformation rates, made the phase unwrapping a complex procedure. The topographic component, including both the roughness and vegetation cover of the landslide, can create artifacts (e.g., layover or foreshortening) responsible for sudden variations in slopes. Thus, an incorrectly unwrapped interferometric phase induces inaccurate displacement rates due to possible phase jumps $(2 \pi)$ [11]. To overcome this limitation, in this study the unwrapping process was initiated from a reference point (DGPS) located in a stable and coherent area, outside the landslide boundaries. As demonstrated by Schlögel et al. [73] and Teshebaeva et al. [12], the use of L-band in combination to C-band SAR images could help obtain better results by reducing time decorrelation effects. L-band acquisitions may be more suitable for highly vegetated areas as well as larger displacements. Another limitation of D-InSAR is the loss of coherence when confronted to rapid displacements or changes in land cover (e.g., agriculture). Additionally, by increasing the 
frequency of SAR acquisitions, the temporal decorrelation decreases as well. In the case of Mailuu-Suu, the use of Sentinel-1A, with only 12 days of repeat cycle, enabled us to observe some precursors before the main reactivation. It is noteworthy that for certain well-covered areas, the combination of Sentinel-1A and Sentinel-1B allows shorter return periods of 6 days. However, the effectiveness of this technique is counterbalanced by its numerous limitations. The main sources of decorrelation are linked to meteorological conditions, spatial and temporal resolutions, magnitudes, velocities, and orientation of the movements, or even variations in soil properties.

Although radar analyses can only highlight slow displacements because the limit of detectability is a function of the wavelength of the sensor, abrupt topographic modifications as well as the evolution of the land cover can be underlined through change detection. This can be achieved using several techniques such as the difference in DEMs, NDVIs or with a multitemporal optical analysis. Variations in surface topography can be used to delimit the depletion and accumulation zones. Our results, based on TanDEM-X and UAV DEMs, revealed that the reactivation of Koytash was characterized by a combined rotational and translational movement. Indeed, soft rocks detached from the scarp (depletion zone) applied an intense, almost vertical, pressure on the material below which caused an uplift in the foot (accumulation zone). By contrast, due to the superficial deformation of the Tektonik landslide, we could assume that the displacement was more likely translational. The performance of this technique is based on the quality of the DEMs. Depending on their coordinate systems and their georeferencing, the comparison and the difference between the products will be more or less exploitable. In the case of the Mailuu-Suu Valley, DGPS points, collected in August 2017 during the field campaign, were used to adjust raw DEMs and to ensure the accuracy of the results. However, such corrections can sometimes lead to significant errors, which must be considered. Therefore, it is essential to test the overlapping compatibility of the input files. Moreover, even though DEMs created on the basis of drone acquisitions have highly superior resolution, they can only be collected on a local scale because they are extremely time-consuming. Nevertheless, high-resolution DEMs are widely used to estimate the volume of displaced geological material [18,74,75].

Studying changes in land cover using NDVI is frequently used to survey the evolution of landslides and has been extensively applied to landslide monitoring studies [19,20,23]. A NDVI analysis of the Mailuu-Suu region, based on five landslide inventories spanning the past 50 years (1962, 1984, 1996, 2002, and 2007), demonstrated the efficiency of using NDVI to detect new sliding activation [23]. In this study, we used vegetation indices to highlight deformation zones and verify if our findings coincided with the D-InSAR results. On the basis of the difference of NDVI map, we observed bright areas (i.e., soil denudation) and darker zones (i.e., growing vegetation). As expected, bright areas were identified within the landslides' boundaries, but also outside the collapsed zones. These might indicate the seasonal variability marked by a strong difference in the vegetation cover depending on the periods of acquisition of the two images (e.g., end of spring (June) and end of summer (October)). Normalization, pixel-by-pixel, of the images by the average NDVI value could possibly mitigate this seasonal effect. However, many parameters (e.g., humidity and anthropogenic changes in land use) must also be considered in order to distinguish the zones that are truly reactivated. Nonetheless, in the case of this study, NDVI was used as a complementary qualitative analysis to verify if the landslide boundaries coincided with important changes in vegetation.

The reactivation of Koytash and Tektonik was also observed in the multitemporal optical analysis showing the evolution of the landslides since 2007. Koytash's recent reactivation can be considered as the most important failure event since the first movements were detected in the 1960s [76]. This massive collapse led to the obstruction of the Mailuu-Suu River forming a dam and subsequently a lake. As the level of water rises, the lake becomes prone to contamination from an upstream uranium tailing and thus represents an important environmental risk for potential water pollution. In 2017, the level of the lake almost reached the toe of this nuclear waste tailing. The formation of this lake may also be a direct threat to the local populations due to related floods. 
Considering the actual climatic context, this study highlighted the importance of understanding the major triggering role of meteorological factors affecting the (re)activation of landslides. To support the remote sensing analysis, and in order to better understand the influence of weather on natural hazards occurrence in Central Asia, we analyzed different potential triggers of the activation. The meteorological analysis performed in the frame of this study demonstrated the triggering role of rainfall combined with the rapid snow melt in the reactivation process as it had already been demonstrated for Kyrgyzstan [77] but also for other regions $[78,79]$. The significant concentration of rain as well as the sudden snowmelt contributed to the water saturation of the soil before Koytash's failure. These predominant weather settings may have conditioned the deformation just before the reactivation, by increasing the pore pressure and thus the mobility of the sediments. Both the Koytash and Tektonik landslides are located in the bed of the Mailuu-Suu valley (Figure 3a). Therefore, during rainfall and the melting of snow caps upstream, water flows through the valley following the Mailuu-Suu River. Furthermore, the landslides are located on steep slopes with overhanging mountains from where surface runoff also flows after the snow melts and intense rainfall. Due to the triggering role of precipitations, it would be justified to automate the daily calculation of meteorological statistics and develop an early warning system to alert the surrounding populations in case of an upcoming disaster. For example, in Africa, Monsieurs et al. [66] were able to determine a rainfall threshold over which landslide susceptibility increases considerably.

With a perpetual increasing number of landslides, studies at regional scale become more and more necessary. With the current technological advances in satellite data, we are now able to process larger amounts of data and span wider areas. However, local and detailed analyses remain crucial when considering landslides such as Koytash and Tektonik that are recurrently reactivated and represent an important threat to surrounding populations. Due to the great density of landslides and the related risks, the Mailuu-Suu region is and will remain a critical area requiring continuous monitoring.

\section{Conclusions}

The aim of this study was to investigate the recent behavior of two landslides-Koytash and Tektonik-in the Mailuu-Suu Valley, Kyrgyzstan. This study was divided into three main objectives: a comparison of multitemporal DEMs, a D-InSAR analysis, and an analysis by optical remote sensing. To better understand the geo-environmental conditions causing the reactivation of the Koytash and Tektonik landslides, we also performed a complementary meteorological analysis. We showed that intense precipitations as well as the rapid melting of an important snowcap contributed to the activation of these two and many other landslides in this region in 2017. However, by creating displacement and velocity maps, the InSAR analysis revealed signs of sliding activity long before the last rupture of Koytash and Tektonik. This indicates that these landslides result from long-term deformations partly related to creeping. Indeed, InSAR allows the measurement of small magnitude displacements that are often not visible in the field. Although this method is not able to detect rapid movements (e.g., the collapse of landslides), InSAR can be used to monitor large-scale areas and identify long-term precursory deformations. Another major limitation is that InSAR measures displacements along the LOS that cannot be interpreted in 3D. Nonetheless, due to the open access availability of SAR acquisitions with short repeat cycles (e.g., 6 days for Sentinel 1A \& B), InSAR is a powerful tool to monitor areas prone to landslides and is thus playing a key role in risk management.

Unlike InSAR, NDVI is a change detection method capable of highlighting the rapid evolution of vegetation. The difference of NDVI, between 2016 and 2017, identified several areas of landslide related land cover change, including the failure of Koytash and Tektonik. Nevertheless, anthropogenic changes in land use or seasonal variations in vegetation cover, depending on the acquisition date, may lead to misinterpretations of the results. Therefore, as shown in this study, NDVI can be used as a complementary qualitative analysis for landslide monitoring, capable of confirming deformations zones identified through InSAR. Similarly to NDVI, the multitemporal optical analysis highlighted deformation zones. The use of high-resolution optical images allows the delimitation of landslide boundaries, enabling precise surface calculations, which is not always possible with other remote 
sensing techniques. By mapping the evolution of the landslides in the Mailuu-Suu Valley, this optical analysis revealed that $30 \%$ of total landslide surface was reactivated in 2017 . Additionally to the previous methods, we created a post-landslide DEM using UAV imagery, only possible at a local scale. The comparison of the latter with a pre-landslide TanDEM-X DEM, allowed us to determine a maximal accumulation of $30.13 \mathrm{~m}$ and a maximal depletion of $41.4 \mathrm{~m}$. This evolution of the topography demonstrated that the collapse of the upper part of Koytash pushed on the underlying layers, which transferred the pressure downslope, resulting in an uplift due to the push-up effect and sliding material aggradation. When studying recent reactivations, post-landslide DEMs are rarely available, and it is therefore necessary to create a new DEM. In conclusion, the combination of radar and optical data revealed the recent landslide activity while the meteorological analysis helped us to identify the triggering factors responsible for the collapse of numerous landslides in Kyrgyzstan in spring 2017. The inherent limitations of the remote sensing methods used in this work, despite their considerable advantages, show that it is useful and essential to combine each of the techniques in order to obtain complete and conclusive results. It is therefore crucial to pursue the study of mass movements, as well as the development of novel cutting-edge techniques, to better understand their triggering conditions and, eventually, anticipate their rupture.

Author Contributions: Conceptualization, H.-B.H., R.S. and V.P.; methodology, formal analysis, and validation, R.S. and V.P.; investigation, V.P.; writing-original draft preparation, V.P.; writing - review and editing, H.-B.H., R.S. and C.B.; visualization, V.P.; supervision, H.-B.H., R.S. and C.B. All authors have read and agreed to the published version of the manuscript.

Funding: V.P.'s three-month internship at the European Centre for Space Applications and Telecoms, ECSAT (Harwell, UK) was funded by the ESA Climate Office.

Acknowledgments: We thank the ESA Climate Office and the Spatial Centre of Liège for their fruitful collaboration. We acknowledge Fabrizio Pacini (Terradue) and Pablo Blanco (Tre-Altamira) supporting the FASTVEL algorithm access in the Geohazard Exploitation Platform (GEP). We are grateful to Isakbek Torgoev (GEOPRIBOR) for providing the in situ meteorological data. We also thank Philippe Cerfontaine (University of Liège) for his contribution during the field campaign carried out in summer 2017. He collected the UAV images and later produced the related high-resolution DEM.

Conflicts of Interest: The authors declare no conflicts of interest.

\section{Appendix A}

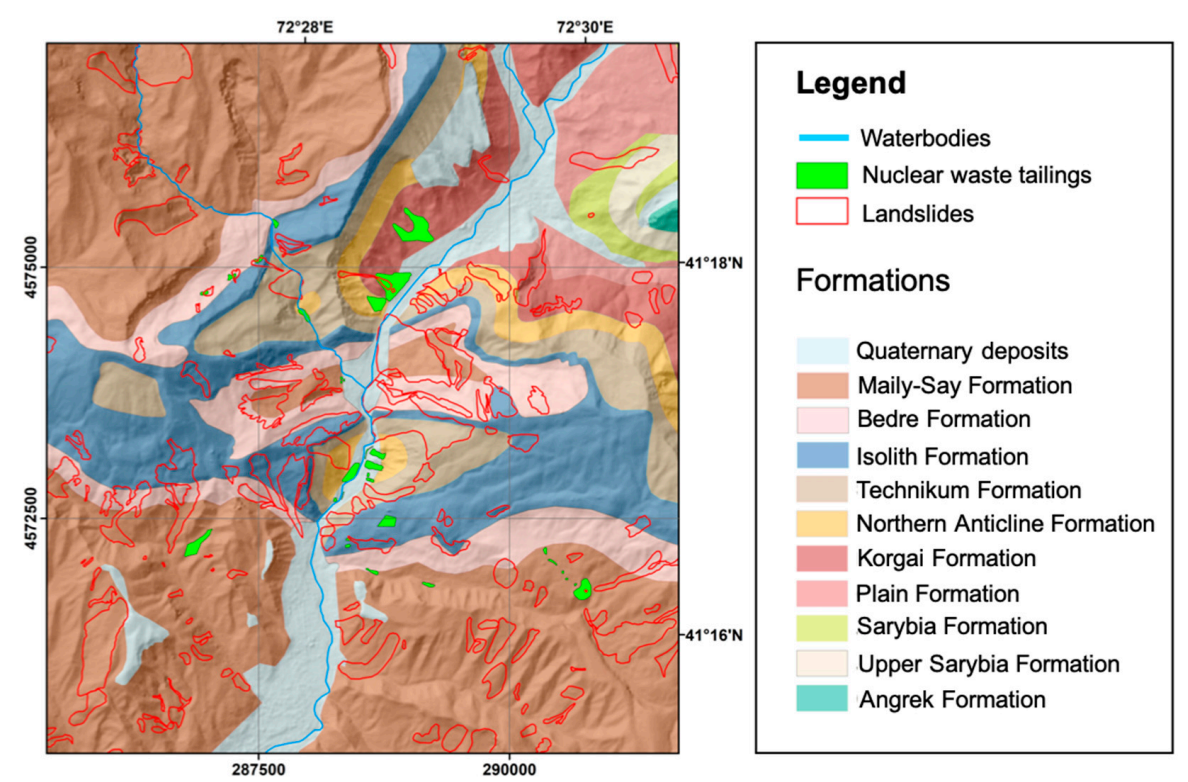

Figure A1. Geological map projected on the TanDEM-X $12 \mathrm{~m}$ hillshade of the Mailuu-Suu target area, with the location of nuclear waste tailings (green) and landslides (red outlines), as mapped by Schlögel et al. [23]. 


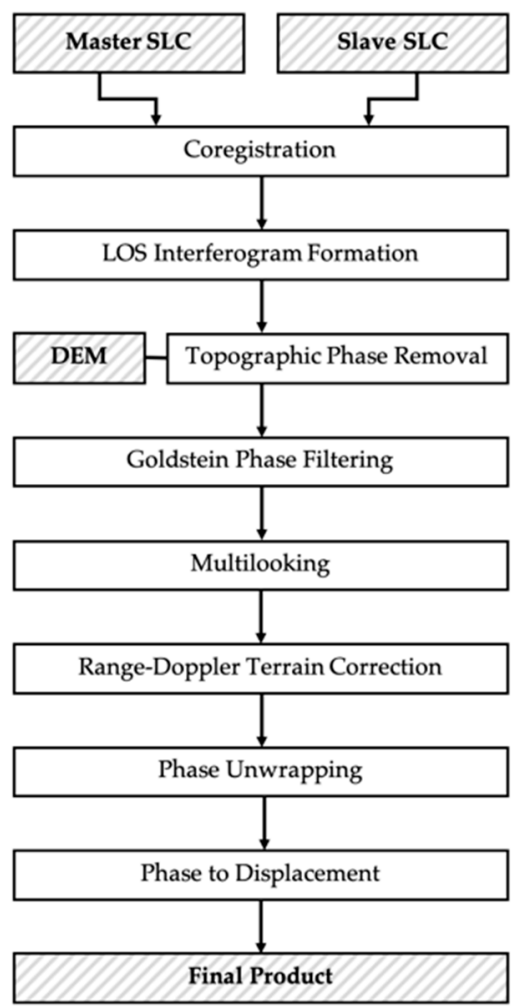

Figure A2. Flowchart of the successive operations carried out for the generation of an interferogram. Hatched blocks represent inputs and outputs while the main actions are in white.

Table A1. Comparison between the altitudes from the Differential Global Positioning System (DGPS) stable ground control points (GCPs) and the DEMs, and calculation of the mean differences.

\begin{tabular}{cccccc}
\hline $\begin{array}{c}\text { Ground Control Points } \\
\text { (GCPs) }\end{array}$ & $\mathbf{1 1}$ & $\mathbf{1 3}$ & $\mathbf{2 3}$ & $\mathbf{2 4}$ & $\begin{array}{c}\boldsymbol{\Delta} \text { Mean } \\
\text { DGPS-DEM }\end{array}$ \\
\hline Longitude & 72.483867 & 72.479250 & 72.476339 & 72.476217 & \\
Latitude (DD) & 41.282283 & 41.293169 & 41.285775 & 41.284550 & \\
DGPS altitude (m) & 1271.50 & 1018.50 & 982.60 & 957.10 & \\
SRTM alt (m) & 1305.87 & 1056.50 & 1020.21 & 990.92 & \\
DDGPS-SRTM (m) & -34.37 & -38.00 & -37.61 & -33.82 & -35.95 \\
SPOT alt (m) & 1292.00 & 1050.00 & 994.00 & 987.00 & \\
DDGPS-SPOT (m) & -20.50 & -31.50 & -11.40 & -29.90 & -23.33 \\
ASTER alt (m) & 1301.46 & 1050.83 & 1008.95 & 986.63 & \\
$\Delta$ DGPS-ASTER (m) & -29.96 & -32.33 & -26.35 & -29.53 & -29.54 \\
TanDEM-X alt (m) & 1265.88 & 1013.79 & 981.95 & 949.87 & \\
$\Delta$ DGPS-TanDEM-X (m) & 5.62 & 4.71 & 0.65 & 7.23 & 4.55 \\
\hline
\end{tabular}

\section{References}

1. Klein, J.A.; Tucker, C.M.; Steger, C.E.; Nolin, A.; Reid, R.; Hopping, K.A.; Yeh, E.T.; Pradhan, M.S.; Taber, A.; Molden, D.; et al. An Integrated Community and Ecosystem-Based Approach to Disaster Risk Reduction in Mountain Systems. Environ. Sci. Policy 2019, 94, 143-152. [CrossRef]

2. Zhao, C.; Lu, Z. Remote Sensing of Landslides-A Review. Remote Sens. 2018, 10, 279. [CrossRef]

3. Saponaro, A.; Pilz, M.; Bindi, D.; Parolai, S. The Contribution of EMCA to Landslide Susceptibility Mapping in Central Asia. Ann. Geophys. 2015, 58. [CrossRef]

4. Roessner, S.; Wetzel, H.U.; Kaufmann, H.; Sarnagoev, A. Potential of Satellite Remote Sensing and GIS for Landslide Hazard Assessment in Southern Kyrgyzstan (Central Asia). Nat. Hazards 2005, 35, 395-416. [CrossRef] 
5. Havenith, H.B.; Torgoev, I.; Meleshko, A.; Alioshin, Y.; Torgoev, A.; Danneels, G. Landslides in the Mailuu-Suu Valley, Kyrgyzstan - Hazards and Impacts. Landslides 2006, 3, 137-147. [CrossRef]

6. Havenith, H.-B.B.; Umaraliev, R.; Schlögel, R.; Torgoev, I.; Ruslan, U.; Schlogel, R.; Torgoev, I. Past and Potential Future Socioeconomic Impacts of Environmental Hazards in Kyrgyzstan. In Kyrgyzstan: Political, Economic and Social Issues; Olivier, A.P., Ed.; Nova Science Publishers, Inc.: Hauppauge, NY, USA, 2017; pp. 63-113.

7. Behling, R.; Roessner, S. Spatiotemporal Landslide Mapper for Large Areas Using Optical Satellite Time Series Data. In Advancing Culture of Living with Landslides; Sassa, K., Mikoš, M., Yin, Y., Eds.; Springer International Publishing: Cham, Switzerland, 2017; pp. 143-152.

8. Lu, Z.; Dzurisin, D. InSAR Imaging of Aleutian Volcanoes; Springer: Berlin/Heidelberg, Germany, 2014.

9. Massonnet, D.; Feigl, K.L. Radar Interferometry and Its Application to Changes in the Earth's Surface. Rev. Geophys. 1998, 36, 441-500. [CrossRef]

10. Ouchi, K. Recent Trend and Advance of Synthetic Aperture Radar with Selected Topics. Remote Sens. 2013, 5, 716-807. [CrossRef]

11. Schlögel, R.; Doubre, C.; Malet, J.P.; Masson, F. Landslide Deformation Monitoring with ALOS/PALSAR Imagery: A D-InSAR Geomorphological Interpretation Method. Geomorphology 2015, 231, 314-330. [CrossRef]

12. Teshebaeva, K.; Roessner, S.; Echtler, H.; Motagh, M.; Wetzel, H.U.; Molodbekov, B. ALOS/PALSAR InSAR Time-Series Analysis for Detecting Very Slow-Moving Landslides in Southern Kyrgyzstan. Remote Sens. 2015, 7, 8973-8994. [CrossRef]

13. Wauthier, C. InSAR Applied to the Study of Active Volcanic and Seismic Areas in Africa. Ph.D. Thesis, Université de Liège, Liège, Belgium, 2011.

14. Peyret, M.; Djamour, Y.; Rizza, M.; Ritz, J.-F.; Hurtrez, J.-E.; Goudarzi, M.A.; Nankali, H.; Chéry, J.; Le Dortz, K.; Uri, F. Monitoring of the Large Slow Kahrod Landslide in Alborz Mountain Range (Iran) by GPS and SAR Interferometry. Eng. Geol. 2008, 100, 131-141. [CrossRef]

15. Handwerger, A.L.; Roering, J.J.; Schmidt, D.A. Controls on the Seasonal Deformation of Slow-Moving Landslides. Earth Planet. Sci. Lett. 2013, 377-378, 239-247. [CrossRef]

16. Colesanti, C.; Wasowski, J. Investigating Landslides with Space-Borne Synthetic Aperture Radar (SAR) Interferometry. Eng. Geol. 2006, 88, 173-199. [CrossRef]

17. Jebur, M.N.; Pradhan, B.; Tehrany, M.S. Detection of Vertical Slope Movement in Highly Vegetated Tropical Area of Gunung Pass Landslide, Malaysia, Using L-Band InSAR Technique. Geosci. J. 2014, 18, 61-68. [CrossRef]

18. Dai, K.; Li, Z.; Tomás, R.; Liu, G.; Yu, B.; Wang, X.; Cheng, H.; Chen, J.; Stockamp, J. Monitoring Activity at the Daguangbao Mega-Landslide (China) Using Sentinel-1 TOPS Time Series Interferometry. Remote Sens. Environ. 2016, 186, 501-513. [CrossRef]

19. Behling, R.; Roessner, S.; Kaufmann, H.; Kleinschmit, B. Automated Spatiotemporal Landslide Mapping over Large Areas Using Rapideye Time Series Data. Remote Sens. 2014, 6, 8026-8055. [CrossRef]

20. Hölbling, D.; Friedl, B.; Eisank, C. An Object-Based Approach for Semi-Automated Landslide Change Detection and Attribution of Changes to Landslide Classes in Northern Taiwan. Earth Sci. Informatics 2015, 8, 327-335. [CrossRef]

21. Stumpf, A.; Malet, J.P.; Allemand, P.; Ulrich, P. Surface Reconstruction and Landslide Displacement Measurements with Pléiades Satellite Images. ISPRS J. Photogramm. Remote Sens. 2014, 95, 1-12. [CrossRef]

22. Zylshal; Sulma, S.; Yulianto, F.; Nugroho, J.T.; Sofan, P. A Support Vector Machine Object Based Image Analysis Approach on Urban Green Space Extraction Using Pleiades-1A Imagery. Model. Earth Syst. Environ. 2016, 2, 1-12. [CrossRef]

23. Schlogel, R.; Torgoev, I.; De Marneffe, C.; Havenith, H.B. Evidence of a Changing Size-Frequency Distribution of Landslides in the Kyrgyz Tien Shan, Central Asia. Earth Surf. Process. Landf. 2011, 36, 1658-1669. [CrossRef]

24. Behling, R.; Roessner, S.; Golovko, D.; Kleinschmit, B. Derivation of Long-Term Spatiotemporal Landslide Activity-A Multi-Sensor Time Series Approach. Remote Sens. Environ. 2016, 186, 88-104. [CrossRef]

25. Li, Z.; Shi, W.; Myint, S.W.; Lu, P.; Wang, Q. Semi-Automated Landslide Inventory Mapping from Bitemporal Aerial Photographs Using Change Detection and Level Set Method. Remote Sens. Environ. 2016, 175, $215-230$. [CrossRef] 
26. Havenith, H.B.; Jongmans, D.; Faccioli, E.; Abdrakhmatov, K.; Bard, P.Y. Site Effect Analysis around the Seismically Induced Ananevo Rockslide, Kyrgyzstan. Bull. Seismol. Soc. Am. 2002. [CrossRef]

27. Havenith, H.B.; Torgoev, A.; Schlögel, R.; Braun, A.; Torgoev, I.; Ischuk, A. Tien Shan Geohazards Database: Landslide Susceptibility Analysis. Geomorphology 2015, 249, 32-43. [CrossRef]

28. Haberland, C.; Abdybachaev, U.; Schurr, B.; Wetzel, H.U.; Roessner, S.; Sarnagoev, A.; Orunbaev, S.; Janssen, C. Landslides in Southern Kyrgyzstan: Understanding Tectonic Controls. Eos 2011, 92, 169-170. [CrossRef]

29. Torgoev, I.; Aleshyn, U.; Havenith, H. Impact of Uranium Mining and Processing on the Environment of Mountainous Areas of Kyrgyzstan. In Uranium in the Aquatic Environment; Merkel, B.J., Planer-Friedrich, B., Wolkersdorfer, C., Eds.; Springer Berlin Heidelberg: New York, NY, USA, 2002; pp. 1-6.

30. Vandenhove, H.; Quarch, H.; Sweeck, L.; Sillen, X.; Mallants, D. Remediation of Uranium Mining and Milling Tailing in Mailuu-Suu District of Kyrgyzstan; Tacis Project N SCRE1/N³8; SCK CEN: Mol, Belgium, 2003.

31. Saponaro, A.; Pilz, M.; Wieland, M.; Bindi, D.; Moldobekov, B.; Parolai, S. Landslide Susceptibility Analysis in Data-Scarce Regions: The Case of Kyrgyzstan. Bull. Eng. Geol. Environ. 2015, 74, 1117-1136. [CrossRef]

32. Lollino, G.; Giordan, D.; Crosta, G.B.; Corominas, J.; Azzam, R.; Wasowski, J.; Sciarra, N. Engineering Geology for Society and Territory_-Volume 2: Landslide Processes; Springer: Berlin, Germany, 2015; Volume 2, pp. 1-2177.

33. Torgoev, I.; Abdrakhmatov, K.; Kasymbek, S.U.; Strom, A.L.; Kristekova, M.; Havenith, H.; Korup, O. Prevention of Landslide Dam Disasters in the Tien Shan, Kyrgyz Republic; NATO: Brussels, Belgium, 2012.

34. Torgoev, I.A.; Aleshin, Y.G.; Meleshko, A.V.; Havenith, H.B. Hazard Mitigation for Landslide Dams in Mailuu-Suu Valley (Kyrgyzstan). Ital. J. Eng. Geol. Environ. 2006, 99-102.

35. Danneels, G.; Bourdeau, C.; Torgoev, I.; Havenith, H.B. Geophysical Investigation and Dynamic Modelling of Unstable Slopes: Case-Study of Kainama (Kyrgyzstan). Geophys. J. Int. 2008, 175, 17-34. [CrossRef]

36. Havenith, H.-B. Landslides Triggered by Earthquakes-Experimental Studies in the Tien Shan Mountains (Central Asia) and Dynamic Modelling. Ph.D. Thesis, University of Liège, Liège, Belgium, 2002.

37. Schlögel, R. Detection of Recent Landslides in Maily-Say Valley, Kyrgyz Tien Shan, Based on Field Observations and Remote Sensing Data. Master's Thesis, University of Liège, Liège, Belgium, 2009.

38. Torgoev, I. Personal Communication; GEOPRIBOR-Scientific Engineering Center: Bishkek, Kyrgyzstan, 2017.

39. Giorgio, H.-Ö.; Markus, K.; Wolfhart, P.; Nedim, R. The "Tektonik" Landslide at Mailuu Suu, Kyrgyz Republic. In Engineering Geology for Society and Territory-Volume 2; Springer International Publishing: Cham, Switherland, 2015; Volume 2, pp. 1055-1059.

40. Abdrakhmatov, K.; Havenith, H.B.; Delvaux, D.; Jongmans, D.; Trefois, P. Probabilistic PGA and Arias Intensity Maps of Kyrgyzstan (Central Asia). J. Seismol. 2003. [CrossRef]

41. Torgoev, A.; Havenith, H.B. 2D Dynamic Studies Combined with the Surface Curvature Analysis to Predict Arias Intensity Amplification. J. Seismol. 2016, 20, 711-731. [CrossRef]

42. Torgoev, I.; Niyazov, R.; Havenith, H.-B. Tien-Shan Landslides Triggered by Earthquakes in Pamir-Hindukush Zone. In Landslide Science and Practice; Margottini, C., Canuti, P., Sassa, K., Eds.; Springer: Berlin/Heidelberg, Germany, 2013; pp. 191-197.

43. Jaud, M.; Passot, S.; Le Bivic, R.; Delacourt, C.; Grandjean, P.; Le Dantec, N. Assessing the Accuracy of High Resolution Digital Surface Models Computed by PhotoScan®and MicMac®in Sub-Optimal Survey Conditions. Remote Sens. 2016, 8, 465. [CrossRef]

44. Bardi, F.; Frodella, W.; Ciampalini, A.; Bianchini, S.; Del Ventisette, C.; Gigli, G.; Fanti, R.; Moretti, S.; Basile, G.; Casagli, N. Integration between Ground Based and Satellite SAR Data in Landslide Mapping: The San Fratello Case Study. Geomorphology 2014, 223, 45-60. [CrossRef]

45. Bamler, R.; Hartl, P. Synthetic Aperture Radar Interferometry. Inverse Probl. 1998, 14, 1-54. [CrossRef]

46. Torres, R.; Snoeij, P.; Geudtner, D.; Bibby, D.; Davidson, M.; Attema, E.; Potin, P.; Rommen, B.Ö.; Floury, N.; Brown, M.; et al. GMES Sentinel-1 Mission. Remote Sens. Environ. 2012, 120, 9-24. [CrossRef]

47. Interferometric Synthetic Aperture Radar-Geoscience Australia. Available online: https://www.ga.gov.au/ scientific-topics/positioning-navigation/geodesy/geodetic-techniques/interferometric-synthetic-aperture-radar (accessed on 16 March 2020).

48. Pepe, A.; Calò, F. A Review of Interferometric Synthetic Aperture RADAR (InSAR) Multi-Track Approaches for the Retrieval of Earth's Surface Displacements. Appl. Sci. 2017, 7, 1264. [CrossRef]

49. Samsonov, S.; Dille, A.; Dewitte, O.; Kervyn, F.; D’Oreye, N. Satellite Interferometry for Mapping Surface Deformation Time Series in One, Two and Three Dimensions: A New Method Illustrated on a Slow-Moving Landslide. Eng. Geol. 2020, 266, 105471. [CrossRef] 
50. Nobile, A.; Dille, A.; Monsieurs, E.; Basimike, J.; Bibentyo, T.; D’Oreye, N.; Kervyn, F.; Dewitte, O. Multi-Temporal DInSAR to Characterise Landslide Ground Deformations in a Tropical Urban Environment: Focus on Bukavu (DR Congo). Remote Sens. 2018, 10, 626. [CrossRef]

51. Tiwari, A.; Narayan, A.B.; Dwivedi, R.; Dikshit, O.; Nagarajan, B. Monitoring of Landslide Activity at the Sirobagarh Landslide, Uttarakhand, India, Using LiDAR, SAR Interferometry and Geodetic Surveys. Geocarto Int. 2020, 35, 535-558. [CrossRef]

52. Barra, A.; Solari, L.; Béjar-Pizarro, M.; Monserrat, O.; Bianchini, S.; Herrera, G.; Crosetto, M.; Sarro, R.; González-Alonso, E.; Mateos, R.; et al. A Methodology to Detect and Update Active Deformation Areas Based on Sentinel-1 SAR Images. Remote Sens. 2017, 9, 1002. [CrossRef]

53. Imamoglu, M.; Kahraman, F.; Cakir, Z.; Sanli, F.B. Ground Deformation Analysis of Bolvadin (W. Turkey) by Means of Multi-Temporal InSAR Techniques and Sentinel-1 Data. Remote Sens. 2019, 11, 1069. [CrossRef]

54. Yang, B.; Xu, H.; Liu, W.; Ge, J.; Li, C.; Li, J. An Improved Stanford Method for Persistent Scatterers Applied to 3D Building Reconstruction and Monitoring. Remote Sens. 2019, 11, 1807. [CrossRef]

55. Czikhardt, R.; Papco, J.; Bakon, M.; Liscak, P.; Ondrejka, P.; Zlocha, M. Ground Stability Monitoring of Undermined and Landslide Prone Areas by Means of Sentinel-1 Multi-Temporal InSAR, Case Study from Slovakia. Geosciences 2017, 7, 87. [CrossRef]

56. Derauw, D. Phasimétrie Par Radar à Synthèse d'Ouverture; Théorie et Applications. Ph.D. Thesis, Université de Liège, Liège, Belgium, 1999.

57. Galve, J.P.; Pérez-Peña, J.V.; Azañón, J.M.; Closson, D.; Caló, F.; Reyes-Carmona, C.; Jabaloy, A.; Ruano, P.; Mateos, R.M.; Notti, D.; et al. Evaluation of the SBAS InSAR Service of the European Space Agency's Geohazard Exploitation Platform (GEP). Remote Sens. 2017, 9, 1291. [CrossRef]

58. Geohazards-TEP. Available online: https://geohazards-tep.eu/ (accessed on 30 April 2020).

59. Schlögel, R.; Kofler, C.; Gariano, S.L.; Van Campenhout, J.; Plummer, S. Changes in Climate Patterns and Their Association to Natural Hazard Distribution in South Tyrol (Eastern Italian Alps). Sci. Rep. 2020, 10, 5022. [CrossRef] [PubMed]

60. FASTVEL for Displacement Velocity Map Generation. Available online: https://terradue.github.io/doc-tepgeohazards/tutorials/fastvel.html (accessed on 16 April 2020).

61. Stumpf, A.; Malet, J.-P.; Puissant, A.; Travelletti, J. Monitoring of Earth Surface Motion and Geomorphologic Processes by Optical Image Correlation. In Land Surface Remote Sensing; ISTE Press -Elsevier: London, UK, 2016; pp. 147-190.

62. Wasowski, J.; Bovenga, F. Investigating Landslides and Unstable Slopes with Satellite Multi Temporal Interferometry: Current Issues and Future Perspectives. Eng. Geol. 2014, 174, 103-138. [CrossRef]

63. Li, Z.; Shi, W.; Lu, P.; Yan, L.; Wang, Q.; Miao, Z. Landslide Mapping from Aerial Photographs Using Change Detection-Based Markov Random Field. Remote Sens. Environ. 2016, 187, 76-90. [CrossRef]

64. Lillesand, T.M.; Kiefer, R.W.; Chipman, J.W. Remote Sensing and Image Interpretation, 6th ed.; John Wiley \& Sons: Hoboken, NJ, USA, 2008.

65. Pettorelli, N. NDVI from A to Z. In The Normalized Difference Vegetation Index; Oxford University Press: Oxford, UK, 2013; pp. 30-43.

66. Monsieurs, E.; Dewitte, O.; Demoulin, A. A Susceptibility-Based Rainfall Threshold Approach for Landslide Occurrence. Nat. Hazards Earth Syst. Sci. 2019, 19, 775-789. [CrossRef]

67. Schlögel, R.; Malet, J.P.; Doubre, C.; Lebourg, T. Structural Control on the Kinematics of the Deep-Seated La Clapière Landslide Revealed by L-Band InSAR Observations. Landslides 2016, 13, 1005-1018. [CrossRef]

68. Fuhrmann, T.; Garthwaite, M.C. Resolving Three-Dimensional Surface Motion with InSAR: Constraints from Multi-Geometry Data Fusion. Remote Sens. 2019, 11, 241. [CrossRef]

69. Sun, L.; Muller, J.P.; Chen, J. Time Series Analysis of Very Slow Landslides in the Three Gorges Region through Small Baseline SAR Offset Tracking. Remote Sens. 2017, 9, 1314. [CrossRef]

70. Hu, B.; Wang, H.S.; Sun, Y.L.; Hou, J.G.; Liang, J. Long-Term Land Subsidence Monitoring of Beijing (China) Using the Small Baseline Subset (SBAS) Technique. Remote Sens. 2014, 6, 3648-3661. [CrossRef]

71. Tofani, V.; Raspini, F.; Catani, F.; Casagli, N. Persistent Scatterer Interferometry (Psi) Technique for Landslide Characterization and Monitoring. Remote Sens. 2013, 5, 1045-1065. [CrossRef]

72. Zhao, C.; Zhang, Q.; He, Y.; Peng, J.; Yang, C.; Kang, Y. Small-Scale Loess Landslide Monitoring with Small Baseline Subsets Interferometric Synthetic Aperture Radar Technique-Case Study of Xingyuan Landslide, Shaanxi, China. J. Appl. Remote Sens. 2016, 10, 026030. [CrossRef] 
73. Schlögel, R. Quantitative Landslide Hazard Assessment with Remote Sensing Observations and Statistical Modelling. Ph.D. Thesis, University of Strasbourg, Strasbourg, France, 2015.

74. Fan, J.R.; Zhang, X.Y.; Su, F.H.; Ge, Y.G.; Tarolli, P.; Yang, Z.Y.; Zeng, Z. Geometrical Feature Analysis and Disaster Assessment of the Xinmo Landslide Based on Remote Sensing Data. J. Mt. Sci. 2017, 14, 1677-1688. [CrossRef]

75. Fan, X.; Zhan, W.; Dong, X.; van Westen, C.; Xu, Q.; Dai, L.; Yang, Q.; Huang, R.; Havenith, H.B. Analyzing Successive Landslide Dam Formation by Different Triggering Mechanisms: The Case of the Tangjiawan Landslide, Sichuan, China. Eng. Geol. 2018, 243, 128-144. [CrossRef]

76. Schlögel, R.; Braun, A.; Torgoev, A.; Fernandez-Steeger, T.M.; Havenith, H.B.; Schlögel, R.; Braun, A.; Torgoev, A.; Fernandez-Steeger, T.M.; Havenith, H.B. Assessment of Landslides Activity in Maily-Say Valley, Kyrgyz Tien Shan. In Landslide Science and Practice: Landslide Inventory and Susceptibility and Hazard Zoning; Springer: Berlin, Germany, 2011.

77. Golovko, D.; Roessner, S.; Behling, R.; Wetzel, H.U.; Kleinschmit, B. Evaluation of Remote-Sensing-Based Landslide Inventories for Hazard Assessment in Southern Kyrgyzstan. Remote Sens. 2017, 9, 943. [CrossRef]

78. Sassa, K.; Canuti, P.; Yin, Y.; Studies, L. Landslide Science for a Safer Geoenvironment: Volume 3: Targeted Landslides; Springer International Publishing: Cham, Switzerland, 2014; Volume 3.

79. Schulz, W.H.; Coe, J.A.; Ricci, P.P.; Smoczyk, G.M.; Shurtleff, B.L.; Panosky, J. Landslide Kinematics and Their Potential Controls from Hourly to Decadal Timescales: Insights from Integrating Ground-Based InSAR Measurements with Structural Maps and Long-Term Monitoring Data. Geomorphology 2017, 285, 121-136. [CrossRef]

(C) 2020 by the authors. Licensee MDPI, Basel, Switzerland. This article is an open access article distributed under the terms and conditions of the Creative Commons Attribution (CC BY) license (http://creativecommons.org/licenses/by/4.0/). 